\title{
WestVirginiaUniversity
}

THE RESEARCH REPOSITORY @ WVU

Graduate Theses, Dissertations, and Problem Reports

2005

\section{The influence of humanism on the handwriting of Michelangelo Buonarroti}

Robert J. Tallaksen

West Virginia University

Follow this and additional works at: https://researchrepository.wvu.edu/etd

\section{Recommended Citation}

Tallaksen, Robert J., "The influence of humanism on the handwriting of Michelangelo Buonarroti" (2005). Graduate Theses, Dissertations, and Problem Reports. 852.

https://researchrepository.wvu.edu/etd/852

This Thesis is protected by copyright and/or related rights. It has been brought to you by the The Research Repository @ WVU with permission from the rights-holder(s). You are free to use this Thesis in any way that is permitted by the copyright and related rights legislation that applies to your use. For other uses you must obtain permission from the rights-holder(s) directly, unless additional rights are indicated by a Creative Commons license in the record and/ or on the work itself. This Thesis has been accepted for inclusion in WVU Graduate Theses, Dissertations, and Problem Reports collection by an authorized administrator of The Research Repository @ WVU. For more information, please contact researchrepository@mail.wvu.edu. 


\title{
The Influence of Humanism on the Handwriting of Michelangelo Buonarroti
}

\section{Robert J. Tallaksen}

\author{
Thesis submitted to the \\ College of Creative Arts \\ at West Virginia University \\ in partial fulfillment of the requirements
}

for the degree of

\author{
Master of Arts \\ in \\ Art History
}

\author{
Janet E. Snyder, Ph.D., Chair \\ J. Bernard Schultz, Ph.D., Dean of the College \\ Robert R. Hopson, Ph.D.
}

Division of Art
Morgantown, West Virginia
2005

Keywords: Art History, Michelangelo Buonarroti, Handwriting, Paleography, Renaissance, Humanism

Copyright 2005 Robert J. Tallaksen 


\section{ABSTRACT \\ The Influence of Humanism on the Handwriting of Michelangelo Buonarroti}

\section{Robert J. Tallaksen}

The handwriting of Michelangelo Buonarroti underwent a distinct and permanent change between 1497 and 1502. The handwriting of his early letters of 1496 and 1497 is merchantescha, the gothic cursive mercantile script which he would have learned at school. The later handwriting is cancellarescha, a humanistic cursive. It is present in letters, contracts, memoranda, records of accounts, and in annotations on drawings. Both scripts as written by Michelangelo are analyzed paleographically and are compared to examples from instructional writing books of the period. The impossibility of evolution from one script to the other is demonstrated through analysis of the scripts and a review of the history of book hands. The alteration must therefore have been the result of a conscious decision by the artist to modify his handwriting. The decision was made as a result of the influence of Humanism and, to a lesser extent, Neoplatonism. 


\section{Table of Contents}

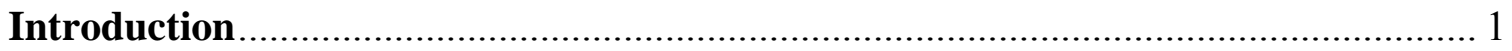

Chapter 1: The Evolution of Book Scripts ............................................................ 3

Chapter 2: Michelangelo's Early Youth and Education ........................................ 9

Chapter 3: The Paleography of Michelangelo's Handwriting............................. 12

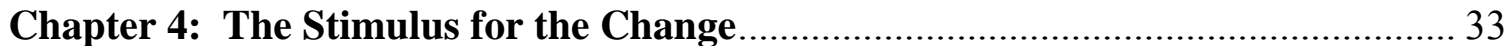

Chapter 5: Rome, and the Decision to Change the Handwriting ............................ 38

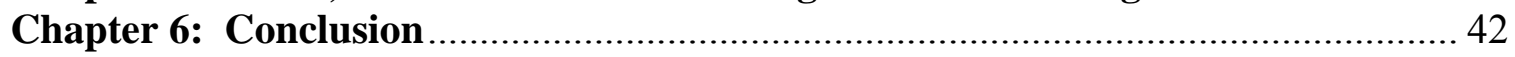

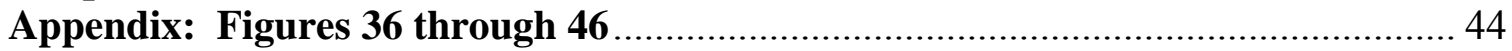

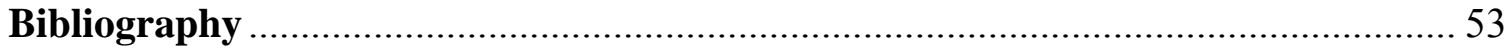

\section{List of Figures}

Figure 1. Michelangelo: Autograph letter, 1 July 1497 and Ricordo, 1508. Florence, Archivio Buonarroti IV, 1 and I, 1.

Figure 2. Examples of humanistic book script from Poggio, 1425-6, and of Caroline minuscule from St. Gall Sacramentary, ca. 825-50.

Figure 3. Handwriting of Niccolò Niccoli, 1427.

Figure 4. Handwriting of Pius II.

Figure 5. Detail from instructional book on Merchantescha by Celebrino, 1525.

Figure 6. Detail from annotation to the Vitruvian Man by Leonardo da Vinci, 1492.

Figure 7. Merchantescha minuscule a from Michelangelo, 1497 Letter, and Tagliente.

Figure 8. Examples of merchantescha $\mathbf{b}, \mathbf{d}, \mathbf{h}$, and $\mathbf{l}$ from 1497 Letter.

Figure 9. Examples of merchantescha long s and f from 1497 Letter and Sonnet.

Figure 10. Dichiarazione, line 23, showing merchantescha and cancellarescha long s.

Figure 11. Examples of merchantescha h from Tagliente, 1497 Letter, and 1497 Sonnet.

Figure 12. Short and long i from 1497 Letter and Sonnet.

Figure 13. Merchantescha double I from Tagliente, 1497 Sonnet, 1497 Letter, and 1501

Dichiarazione.

Figure 14. Merchantescha q from Tagliente, 1497 Sonnet, and 1497 Letter.

Cancellarescha q from Dichiarazione and Arrighi, Operina, 6.

Figure 15. Merchantescha majuscule M from signature of 1497 Letter and from

Palatino. 
Figure 16. Minuscule $\mathbf{g}$ from 1497 Letter, 1497 Sonnet, 1501 Dichiarazione, and Sketch for the Bronze David.

Figure 17. Arrighi, method of construction of cancellarescha minuscule letters.

Figure 18. Cancellarescha a from Contract, Ricordo, Sonnet, Letter, and Sketch for the Bronze David.

Figure 19. Cancellarescha b from Contract; Ricordo, line1; Sonnet; Letter; and Ricordo, line 9.

Figure 20. Cancellarescha d from Contract; Sonnet, line 2; Sonnet, line 8; Ricordo; and Letter.

Figure 21. Cancellarescha f from Arrighi, Dichiarazione, Bronze David Sketch, Contract, Ricordo, and Letter.

Figure 22. Cancellarescha $\mathbf{h}$ from Arrighi, Dichiarazione, Bronze David Sketch (2), Ricordo (2), Contract, and Letter.

Figure 23. Cancellarescha $\mathbf{I}$ and double $\mathbf{I}$ from Arrighi, Bronze David Sketch, Contract, Sonnet, and Letter.

Figure 24. Cancellarescha $\mathbf{q}$ from Arrighi, Dichiarazione, Contract, and Letter.

Figure 25. Cancellarescha long $\mathbf{s}$ from Arrighi, Sonnet, and Letter.

Figure 26. Cancellarescha s from Arrighi, Contract, and Letter.

Figure 27. Signatures of Michelangelo from the 1 July, 1497, Letter and the Sketch for the Bronze David.

Figure 28. Cancellarescha abbreviation for Reverendissimo from Arrighi, Dichiarazione, and Letter.

Figure 29. Revere[ $\mathrm{n}]$ dissi $[\mathrm{m}] \mathrm{o}$ from 1497 Letter.

Figure 30. Cancellarescha $\mathbf{z}$ from Celebrino, 1497 Letter, 1497 Sonnet, and 1508 Sonnet.

Figure 31. Conventional appearance of $\mathbf{t t}$ from 1497 Letter and Dichiarazione.

Figure 32. Examples from Arrighi of use of ligatured ct in place of tt: tratto, tratti, carattheri.

Figure 33. Examples from Michelangelo of use of ligatured $\mathbf{c t}$ in place of $\mathbf{t t}$. Contract: scritta; Sonnet: fatto; 1518 Letter: tutta. 
Figure 34. Abbreviated family tree of scripts showing descent of merchantescha and cancellarescha.

Figure 35. Humanistic cursive handwriting of Angelo Poliziano.

Figure 36. Michelangelo, autograph letter dated 1 July 1497 (detail). Archivio Buonarroti, IV, 1.

Figure 37. Michelangelo, autograph sonnet, 1497. Archivio Buonarroti, XIII, 110.37.

Figure 38. Michelangelo, Declaration (Dichiarazione) concerning the contract for statues for the Piccolomini Altar, Siena, 22 May 1501. Archivio Buonarroti, II-III, 3 verso.

Figure 39. Michelangelo, autograph contract with quarry masters of Carrara for marble for the tomb of Julius II, 10 December 1505. Archivio Buonarroti, II-III, 7 recto. Figure 40. Michelangelo, Sonnet, 1508-12. Archivio Buonarroti, XIII, 111.

Figure 41. Michelangelo, Ricordo, April 1508 (detail). Archivio Buonarroti, I, 1.

Figure 42. Michelangelo, autograph letter to Cardinal Giulio de' Medici, 1518. ArchivioBuonarroti, V, 17.

Figure 43. Michelangelo, Sketch for the Bronze David (and detail), 1501-2. Paris, Louvre, Cabinet des Dessins, INV\# 714 recto, and detail.

Figure 44. Arrighi, from La operina, 6 and 8.

Figure 45. Tagliente, from Lo presento libro, 1524.

Figure 46. Celebrino, from Il modo, 1525. 


\section{Introduction}

Historians in general, and art historians in particular, are fortunate that nearly five hundred of Michelangelo's letters have survived. Most are in his own handwriting. The content of the letters is private and is primarily related to family and financial matters. They were not intended for publication. In the standard English edition of the letters, Ramsden states that they "were not stylistic exercises, but intimate communications addressed to his family and to his friends, often written in a hurry and sometimes under physical and mental stress." Although the letters contain little concerning his personal philosophy and theory of Art, they offer a glimpse into his everyday life and the contemporary influences he experienced. More importantly, a close examination of the artist's handwriting reveals the deliberate alteration he made in its elemental characteristics. The original research based on this observation offers a hitherto unappreciated insight into and adds to our understanding of the influences of Humanism and Neoplatonism on Michelangelo's character and his Art.

The earliest existing letters in Michelangelo's handwriting date from 1496 and 1497 and are written in a gothic mercantile hand called merchantescha that he would have been taught at school in Florence. ${ }^{2}$ No letters are extant from 1497 through 1506, but in annotations on drawings by the end of 1502 and in the letters dating from 1507 and later, there is an astonishing and significant difference may be seen in the character of the artist's handwriting (figure 1). The change is radical, fundamental, and, most notably, permanent. Michelangelo used this new handwriting in all subsequent letters for the remainder of his life as well as in notations on drawings, in short written messages and memoranda, and in ricordi, or records of accounts. The new handwriting is cancellarescha, the style which came to be called "Chancery Cursive" in the early sixteenth century because it had been adopted by the Apostolic Chancery nearly a century previously for record keeping. This thesis explores the nature of Michelangelo's handwriting in both of its distinct forms and explains the reasons for his transformation of

\footnotetext{
${ }^{1}$ Ramsden, 1:xix.

${ }^{2}$ Bardeschi Ciulich (Costanza, 16) notes four letters between 1496 and 1498 . The first one is dated 2 July 1496 (State Archives Florence, Filza LXVIII, Doc. 302). Ramsden (1:3) states that it may be a copy made for Botticelli and is indeed addressed to him on the verso. However, Ramsden's judgment that this copy is not in Michelangelo's handwriting is, in my opinion, incorrect; see chapter 3 below.
} 
it from merchantescha to cancellarescha. In order to do this it is first necessary to review briefly the evolution of book scripts in Europe and their cursive descendants.
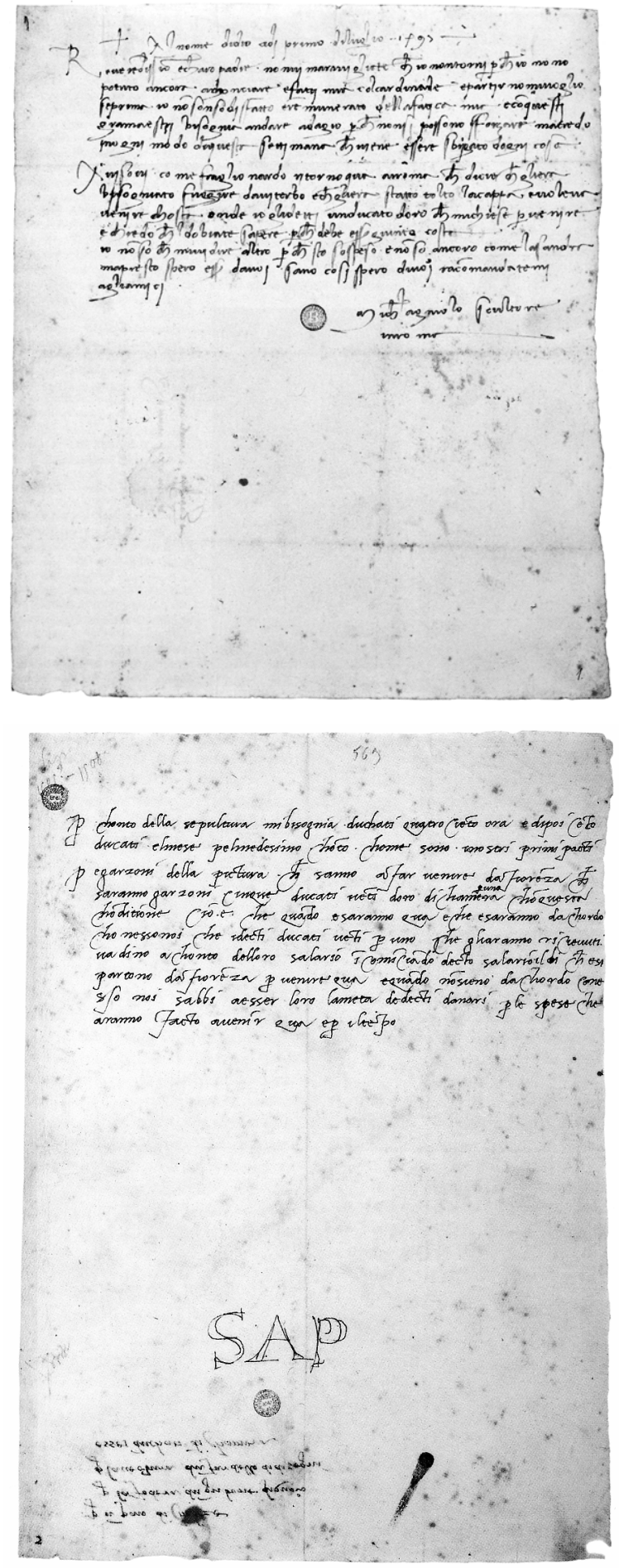

Figure 1. Michelangelo: Autograph letter, 1 July 1497 (above) and Ricordo, 1508. Florence, Archivio Buonarroti IV, 1 and I, 1 . See also details, figures 36 and 41. 


\section{Chapter 1: The Evolution of Book Scripts}

There is a demonstrable progression of book scripts used in Western Europe from the Roman era to the introduction of printing. ${ }^{3}$ An understanding of this development is essential for understanding the change Michelangelo made in his handwriting. Although nomenclature for specific scripts at the various stages is lacking, there is a generally accepted terminology for the broad developmental phases.

The earliest book script, in contrast to everyday cursive handwriting, was Capitalis or "rustic capitals," an upright majuscule hand; that is, it was written between two lines only ${ }^{4}$ with no minuscule or "lower case" letters. It derived from the Roman epigraphic scriptura monumentalis. Manuscripts written in capitalis such as the famous Vergilius Romanus ${ }^{5}$ are still plentiful and its traits have been thoroughly characterized.

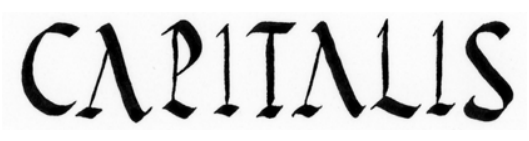

The use of capitalis flourished to the end of the fifth century but it was relatively difficult to write because of the many pen manipulations required. The immediate successor of capitalis, Uncial, evolved during the second to fourth centuries. Uncial was also a majuscule hand, but was faster to write because it was a fusion of capital letterforms with variants which used fewer and less complicated pen-strokes. ${ }^{6}$ Uncial spread from Italy

\section{UNCIAI,}

throughout Europe and developed into the insular system of scripts which was used in the Lindisfarne Gospels and the Book of Kells. By the eighth century, uncial and its relative half-uncial, which included minuscule letter forms, were in common use. In addition, a large number of local and national book hands had appeared, such as Beneventan, Luxeuil, Corbie, and others.

The Holy Roman Emperor Charlemagne (742 or 743-814) was "devoted to the cause of Christianity and Roman civilisation." "7 During his rule, Roman models and the

\footnotetext{
${ }^{3}$ J. Brown, 53-7.

${ }^{4}$ Bischoff, 69.

${ }^{5}$ Vergilius Romanus, Rome, fifth century. Biblioteca Apostolica Vaticana, Ms Vat. Lat. 3867.

${ }^{6}$ Brown \& Lovett, 39.

${ }^{7}$ Jackson, 62.
} 
numerous local, national, and uncial hands were consolidated into the Carolingian or Caroline Minuscule. Beginning in the late eighth century the Caroline minuscule

\section{caroline minufcule}

replaced all its predecessors and by the twelfth century it was used "from Catalonia to East Saxony and Dalmatia, from Denmark to east of Rome." " It was so beautifully proportioned, legible, and pleasing to the eye that we recognize its forms as the basis of lower case letters to the present. There was, however, no Caroline cursive hand. ${ }^{9}$

A new book script now called protogothic appeared in the eleventh century, primarily in areas under Norman and Angevin rule, and it evolved into the next major book hand, Gothic Textura or Textualis. This hand was based on Caroline minuscule

\section{trettlalı}

but the rounded, Romanesque-appearing arches of the Caroline had become elongated, angular, and laterally compressed, and bear a resemblance to the pointed arches of gothic architecture. Some of the other characteristics of textualis included broken verticals, fusions of letters, and, except in Italy, no round strokes at all. The "extension and vertical alignment of all shafts" ${ }^{\prime 10}$ recall the arches and impressive verticals of Gothic architecture and likely reflect the Gothic aesthetic of the time. ${ }^{11}$ Gothic Cursive developed from the gothic textualis and the diplomatic and papal documentary minuscules which were derived from Caroline. Since it was a combination of gothic and Caroline, is also called

\section{baftarda}

Gothic Bastarda or Hybrida. This simplified and more cursive script was introduced into schools and universities in the late thirteenth century. ${ }^{12}$ Loops were common, and the practice of leaving the pen point on the writing surface produced "slings" below the

\footnotetext{
${ }^{8}$ Bischoff, 118 .

${ }^{9}$ Derolez, 54.

${ }^{10}$ Bischoff, 128.

${ }^{11}$ Derolez, 70, feels that the origin of gothic scripts is a reflection of a change in artistic taste and that these scripts and "Gothic codicological features must be considered an expression of the same aesthetic, of a 'Gothic taste' or 'Gothic mood.' It is expressed in verticality, compactness, angularity, pointedness, closedness and framing, and uniformity.” See also E. Panofsky, Gothic Architecture and Scholasticism. New York: Meridian Books, 1957.

12 Bischoff, 140.
} 
writing line, particularly on the bowl of $\mathbf{h}$ and also on the tails of $\mathbf{y}$ and $\mathbf{g}$. The presence of loops reduced its legibility and made distinguishing between letters such as $\mathbf{b}(\mathfrak{b})$ and $\mathbf{v}(\boldsymbol{y})$ difficult. $^{13}$ The gothic cursive was stylized and extensively abbreviated.

By the end of the fourteenth century, the poet Petrarch (1304-74) criticized the gothic script then current in Italy as being hard on his eyes, ${ }^{14}$ and his friend the Humanist and Chancellor of Florence Coluccio di Piero di Salutati (1331-1406) wrote that he desired an edition of Cicero in large letters because of his failing eyesight. ${ }^{15}$ Coluccio was an avid book collector, and some of his books still exist in the Biblioteca Medicea Laurenziana in Florence. Ullman wrote in 1960 that he had examined over one hundred manuscripts owned by Coluccio and that approximately one-third of them originated from the ninth to twelfth centuries. ${ }^{16}$ Since most would have been copied in Caroline minuscule Coluccio was well acquainted with this script, and he judged it to be the lettering style most suitable to replace what he judged to be the crabbed, illegible gothic script. Coluccio was free in giving and lending books and this undoubtedly helped to popularize the script. It is significant that the manuscript of Coluccio's own treatise De verecundia was written in Caroline minuscule, and there are corrections in the author's hand, indicating that it was produced before his death in 1406. The scribe who produced this book and the person directly responsible for the revival of the Caroline minuscule as a humanistic book script in the fifteenth century was Poggio Bracciolini. ${ }^{17}$

Poggio (1380-1459) was a notary, scribe, and tutor in Florence. He was described by Vespasiano da Bisticci, the Florentine librarian, bookseller, Humanist, and advisor of Cosimo de' Medici, as an excellent copyist of the new book hand, which he referred to as lettera antica. ${ }^{18}$ The new Humanist book script, the revived Caroline minuscule, acquired this name because it was thought at the time to be ancient, ${ }^{19}$ in contrast to the

\footnotetext{
${ }^{13}$ Bischoff, 141.

${ }^{14}$ Petrarch characterized the Italian gothic cursive as "vaga ac luxurians and tiring to read." P. Lehmann, "Aufgaben und Anregungen der lateinischen Philologie," in Sitzungsberichte der philosophischphilologischen und der historischen Klasse der Bayerischen Akademie der Wissenschaften, 1918, 17. Quoted in Meiss, 98.

${ }^{15}$ Ullman, 13.

${ }^{16}$ Ullman, 16.

${ }^{17}$ Ullman, 21-57 ; Morison, 32-43.

18 "Fu bellissimo iscrittore di lettera antica..." Vespasiano di Bisticci, Vite di uomini illustri del secolo XV, Milan, 1951, 291. Noted in Ullman, 23.

${ }^{19}$ Morison, 34.
} 
gothic hands, which were termed lettera moderna. Sometime between 1400 and 1402 Poggio copied the first manuscript in a script that modeled on a tenth or eleventh century original. ${ }^{20}$ The new humanistic script was adopted not through the force of an imperial decree as was the original Caroline minuscule, but rather achieved its preeminence because it was adopted enthusiastically and promoted by the Humanists. This promotion has been described as "a piece of private enterprise, the hobby of an intellectual club concerning itself with the criteria of knowledge and necessarily involving a scrutiny of sources, primarily literary, and first of all Latin; it was not adopted officially - in the Papal chancery - until it had already won wide acceptance privately, among the Humanists. ${ }^{, 21}$ In the opinion of the Humanists, the Caroline minuscule, the lettera antica, was older, purer and more beautiful than the gothic scripts in common use, and soon it was being used for the production of books not just in Florence, but also in other cities in which princely libraries were being established: Milan, Ferrara, Mantua, Urbino, Naples, and Rome. Poggio went to Rome in 1403 and became one of the Papal secretaries to Boniface IX, a position which he continued to hold under Innocent VII, Gregory XII, Alexander V, and John XXIII. In 1423, during the reign of Pope Martin V, Poggio became Secretary to the Chancery and was very likely instrumental in the implementation of the new script by the Vatican, because that same year the upright humanistic book script, the lettera antica, was adopted to replace gothic cursive for the writing of papal briefs. A direct comparison of the new humanistic book script as written by Poggio with an example of the fully developed original Caroline minuscule, such as the ninth century St. Gall Sacramentary in the Bodleian Library, Oxford, shows that the two are virtually identical (figure 2).
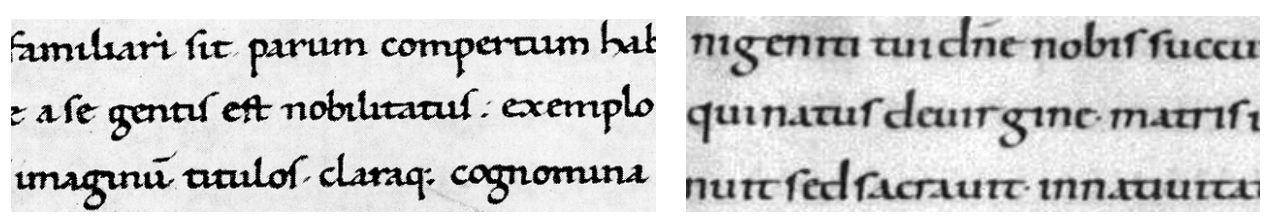

Figure 2. Left, Poggio, $1425-6,{ }^{22}$ and right, St. Gall Sacramentary, ca. $825-50 .^{23}$

\footnotetext{
${ }^{20}$ Bischoff, 146.

${ }^{21}$ Morison, 33.

${ }^{22}$ Rome, Vat. Lat. 1849 , f. 182 r.

${ }^{23}$ Gregorian Sacramentary: St. Gall(?), c.825-50. Oxford, Bodleian Library, MS. Auct. D. 1. 20, fol. 116r.
} 
A close friend of Poggio's in Florence was the distinguished scholar Niccolò Niccoli (1363-1437), a member of the circle of Cosimo de' Medici. It is with Niccoli that there is a momentous change in the history of handwriting. Niccoli was a book collector, and his collection is the nucleus of what is now the Biblioteca Medicea Laurenziana. He encouraged scribes to copy Poggio's style and he owned at least three books that have been attributed to Poggio. ${ }^{24}$ For his own handwriting Niccoli developed a cursive form of the humanistic book hand, a cursive variation that had not existed at the time of the original introduction of Caroline minuscule (figure 3). Among the characteristics visible in Niccoli's hand are the loss of some of the round appearance of the formal book hand, the acquisition of a slant toward the right, and joins and ligatures between some of letters, especially the long looped ligature between $\mathbf{c}$ and $\mathbf{t}^{25}$ This humanistic cursive script became extremely popular, and the successors of Pope Martin V, Eugenius IV (13881447, elected 1431) and Pius II (1405-1464, elected 1458), adopted it for their own handwriting (figure 4). By 1462, during the reign of Pius II and only twenty-five years

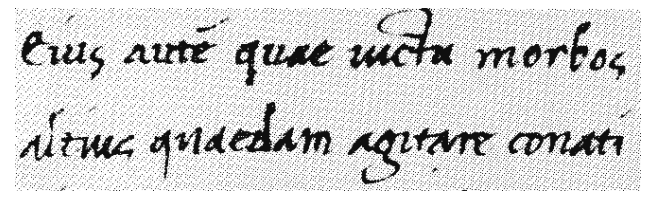

Figure 3. Niccoli, $1427 .^{26}$

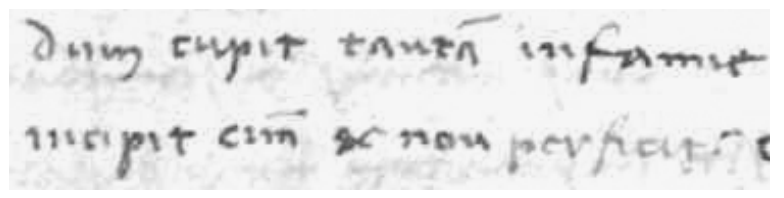

Figure 4. Pius II, between 1458 and $1464 .^{27}$

after Niccoli's death, the cursive version of the humanistic book script invented by him had replaced the upright book hand in the Apostolic Chancery. Furthermore, the cursive script had also been adopted by the chanceries of some of the city-states, including Ferrara and Florence. By the end of the fifteenth century, however, the humanistic upright and cursive hands were practiced by relatively few people, primarily Humanists. The most prevalent script remained merchantescha, a gothic mercantile cursive, with innumerable professional and local variations. It was the same gothic handwriting that

\footnotetext{
24 de la Mare, 49.

${ }^{25}$ This feature appears in the Sketch for the Bronze David. Paris, Louvre, Cabinet des Dessins, INV \#714.

${ }^{26}$ Niccoli, Liber Celsi, 1427. Florence, Biblioteca Medicea Laurenziana 73, 7, f. 3r (detail). "Eius aute[m] quae uictu morbos... altius quaedam agitare conati..."

${ }^{27}$ Pius II, Commentaries. Rome, Biblioteca Apostolica Vaticana, Reg. lat. 1995 fol. 35r (detail).
} 
Petrarch and Coluccio complained of as being difficult to read, ${ }^{28}$ and which Michelangelo learned and used in his youth.

The humanistic cursive, called cancellarescha or "Chancery Cursive" after the Apostolic Chancery, was the direct successor of Niccoli's own cursive handwriting. The chancery cursive became quite popular and was taught throughout Europe, and the first book dedicated to its instruction, La operina by Ludovico Vicentino degli Arrighi (ca. 1475-ca. 1527), a scribe of the Apostolic Chancery, appeared in 1522. La operina is exceptional because it was the first writing manual in which the directions for writing a particular script are given in the script itself, while it also codifies the precise characteristics. In this book, Arrighi puts forward the cursive hand shown in his book as a model "of the writing and regular formation of the characters and particulars of the letters (which today are called Chancery). ${ }^{29}$ He describes the individual pen strokes used to write the letters, how the letters should spring from a geometric form, and gives additional instruction on letter forms, spacing, and composition. It is this handwriting that Michelangelo adopted by the end of 1502, and which he used for the remainder of his life. It will be shown that Michelangelo's formation of his letters conforms exactly to the rules set down by Arrighi in 1522 .

\footnotetext{
${ }^{28}$ Ullman, 13.

${ }^{29}$ Arrighi, Operina, introduction "Al benigno lettore." " $[\mathrm{S}]$ criuere, et regulatamente formare gli caratteri e note delle 1[ette]re (che Cancellaresche hoggi di chiamamo)..."
} 


\section{Chapter 2: Michelangelo's Early Youth and Education}

Michelangelo's father Lodovico (1444-1534) moved his family from Caprese, where he had been podestà, or resident magistrate, when the future artist was less than a month old. Michelangelo was given to be nursed by the daughter of a stonecutter in the Florence suburb of Settignano where Lodovico and his brother Francesco owned a small farm. At some point during his early childhood Michelangelo left Settignano to live with his father and uncle in a house in the Santa Croce quarter of Florence. At his father's direction Michelangelo attended a grammar school in Florence operated by the Humanist Francesco Galeota, also called Francesco da Urbino. Neither Vasari nor Condivi states the age at which Michelangelo was sent; the former says that he was "already grown" and the latter that he was at "the right age." 30 Since Michelangelo entered his apprenticeship with Domenico Ghirlandaio at age fourteen, Tolnay speculates that he was about ten years old when he went to school. ${ }^{31}$ In notes to their translation of Condivi's The Life of Michelangelo, Wohl and Wohl state that he was seven. ${ }^{32}$ There is no specific information about Francesco's Scuola di Gramatica. At the time, however, schools were not merely grammar (i.e., Latin) schools but also provided instruction in the seven liberal arts and sciences, as well as correspondence and the drafting of documents. Humanistic philosophers who had an interest in education held proper handwriting in high regard, and it is certain that training in penmanship was included in the course of instruction. We need only look at two excerpts from humanistic treatises on education to understand the significance of this. In his book De ingenuis moribus et liberalibus adulescentiae studiis liber (The Book Concerning the Character and Liberal Studies of a Freeborn Youth) Pier Paolo Vergerio (1370-1444; Humanist, canonist, and statesman, secretary to Popes Innocent VII and Gregory XII) states that contrary to Greek education, "[d]rawing as it is now practiced is not worthy of a free man, except perhaps insofar as it pertains to writing (for penmanship is actually a form of drawing and sketching); for the rest, it is the business of painters." 33 Even more forceful is the emphasis placed on the subject by

\footnotetext{
${ }^{30}$ Condivi, 8 .

31 Tolnay, 11 .

${ }^{32}$ Condivi, 125.

${ }^{33}$ Kallendorf, 49-51.
} 
Aeneas Silvius Piccolomini, who was elected Pope Pius II in 1458. In his treatise De liberorum educatione (The Education of Boys) written in 1450 for Ladislaus Posthumus, King of Hungary and Bohemia and Duke of Austria, Piccolomini states: "Orthography we divide into two parts: writing clearly and writing correctly. In the first part, one must be sure to form the letters with their proper characteristics, neither too long nor too thick, letting the round, square, extended and curly shapes keep their proper form."”34

There were no regulations for the conduct or governance of schools in Renaissance Italy and although they operated primarily on a system that sold services in a free market, ${ }^{35}$ some were dependent on the government of the city in which they were located. On the evidence of his name, it is likely that Michelangelo's schoolmaster Francesco had a connection with the city of Urbino either through family or education or, because Urbino was a center of humanistic education and because such a connection would likely be good for business, he wished to suggest that he such a connection existed. One of the greatest Humanist innovators in the development of the general education curriculum, Vittorino Ramboldini (1378-1446), called Vittorino da Feltre after his birthplace, was active in Urbino. Duke Federigo III da Montefeltro (1422-82) was himself a student of Vittorino's in Mantua, and Poggio Bracciolini sent his son to study with him. It is very likely that the humanistic educational climate fostered by Vittorino in Urbino would have been reflected in Francesco's school in Florence.

A schoolmaster of the time was independent and the school under his direction either succeeded or did not succeed on the basis of the master's reputation and his teaching ability. The direct reading of classic texts was emphasized over formal grammatical instruction and a school provided a broad education to its students before they chose a career. ${ }^{36}$ Since the purpose of schools of the time was to prepare the student for any specialization, and because proper handwriting was esteemed, handwriting would certainly have formed a part of the curriculum. Michelangelo's teacher Francesco, as a Humanist, would have stressed the subject of handwriting. The script that he would have selected and taught was the one that allowed the student the greatest choice of career; specifically, the gothic script, merchantescha, which was then current in business affairs.

\footnotetext{
${ }^{34}$ Kallendorf, 227.

${ }^{35}$ Grendler, 775 .

${ }^{36}$ Black, 318.
} 
The use of this script was widespread and not only business people and the general public but also other artists used it. Compare, for example, a detail of merchantescha from an instructional manual by Eustachio Celebrino (ca. 1480 - ca. 1535)devoted to merchantescha (figure 5) with a reversed detail from Leonardo da Vinci's annotation to his drawing of the Vitruvian Man (figure 6). ${ }^{37}$

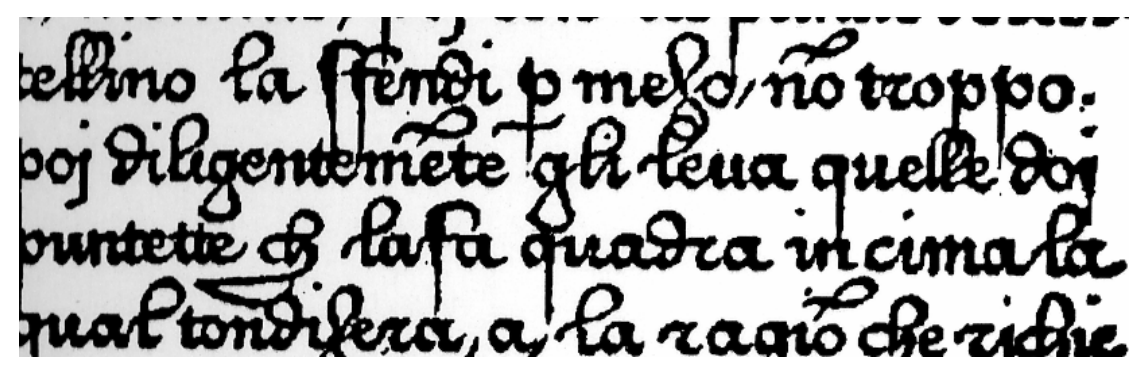

Figure 5. Celebrino, 1525.

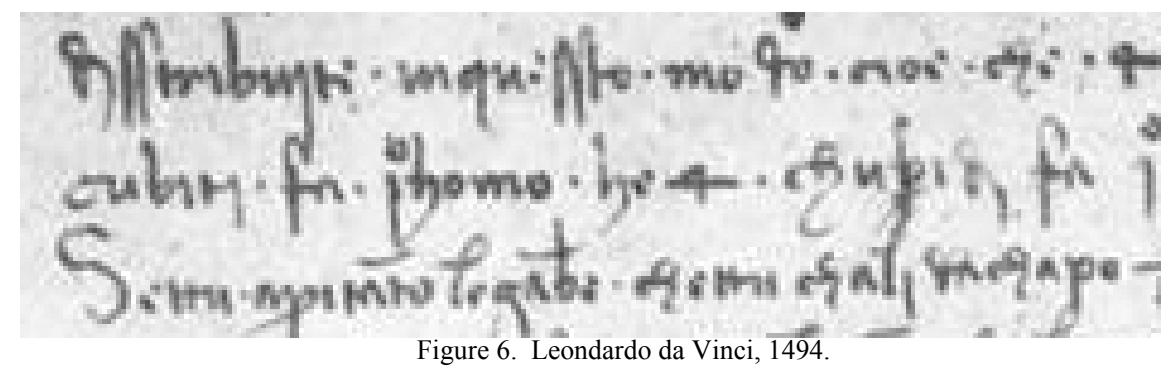

${ }^{37}$ Leonardo da Vinci, Vitruvian Man, 1492. Galleria dell'Accademia, Venice. 


\section{Chapter 3: The Paleography of Michelangelo’s Handwriting}

The fundamental difference between the merchantescha and the cancellarescha scripts, and the impact of this difference on the development of Michelangelo's handwriting, lie at the foundation of the premise of this thesis. It is necessary to examine both scripts in some detail in order to establish and illustrate the differences between them, to demonstrate that evolution from one to the other is not possible, and to show that Michelangelo must have decided to change his handwriting from one to the other.

The gothic script merchantescha, which developed in Italy in the fourteenth and fifteenth centuries from the writing of notaries, was used primarily for correspondence and mercantile records. ${ }^{38}$ Its antecedents were primarily Gothic cursive or cursiva, the most commonly used type of script at that time, and hybrida or bastarda. The cursiva appeared first, beginning in the thirteenth century. Its letter forms are the same as those of the Gothic textualis, altered by a cursive order of pen strokes, or ductus, and it is by nature a stylized cursive. Individual and distinctive letter forms are many, and they include single-stroke and single compartment a, single-stroke looped $\mathbf{d}$ (which in Italy often had the lower loop written clockwise), long $\mathbf{f}$ and $\mathbf{s}$ that reach below the writing line with straight, pointed tails and written with downward and then upward pen strokes. The bowl of the $\mathbf{h}$ reaches below the writing line. Except in Germany and central Europe, $\mathbf{i}$ is written without diacritical marks, and the long $\mathbf{i}$ or "i-longa" resembling modern $\mathbf{j}$ is found in either the final position of a word or after letters consisting of short vertical strokes or minims such as $\mathbf{m}, \mathbf{n}$, and $\mathbf{u}$. Minuscule $\mathbf{q}$ always has a straight or pointed descender. ${ }^{39}$ Bastarda was essentially a variant of cursiva and has few characteristics which can be applied generally except for the ascenders of the tall letters $\mathbf{b}, \mathbf{d}, \mathbf{h}$, and $\mathbf{l}$. Important in of Michelangelo's handwriting is that the loops on these ascenders are lacking and there is an upwards sloping approach stroke from the left. ${ }^{40}$ Bastarda, like its parent cursiva, was in common use throughout Europe though it appeared somewhat later, beginning in the fifteenth century. Developing as a subtype among the bastarda and cursiva hands "in the lower levels of execution," merchantescha has been described

\footnotetext{
${ }^{38}$ Bischoff, 139.

${ }^{39}$ Derolez, 142-9.

${ }^{40}$ Derolez, 164.
} 
as "the handwriting used by the merchants and other business people for their affairs, first in Florence in the first decades of the fourteenth century, and later also in the other cities of Northern and Central Italy. ${ }^{, 41}$ While merchantescha was never important as a book script, it was well recognized as a contemporary script and examples of it in its local variations appear in the famous calligraphic manuals of the sixteenth century. It appears as "Merchantescha" in Arrighi's Il modo (1523). Tagliente includes it in his Lo presento libro (1524) in its Venetian and Florentine variations, with examples titled "La lettera fiorentina bastarda" (i.e., commercial) and "fiorentina naturale" (notarial). Palatino, in his Libro nvovo (1540), shows the Venetian and Florentine hands as well as examples from other cities including Milan, Rome, Siena, Genoa, and Bergamo. A small manual devoted specifically to merchantescha by Eustachio Celebrino (c. 1480 - c. 1535) was published in 1525 . The fact that none of these instructional manuals is contemporary with Michelangelo is not significant, for the letter forms they demonstrate are the same forms that had developed in each script and they had not changed by the time the manuals were written.

We shall examine three documents in Michelangelo's handwriting to assess the merchantescha phase of his handwriting. They are the letter to his father, dated 1 July1497 (Archivio Buonarroti IV, I), a copy of his Sonnet "Qua si fa elmi di chalici e spade," also from 1497 (A. B. XIII, 110), and a preliminary declaration (Dichiarazione) concerning the contract for the statues intended for the Piccolomini altar in Siena, dated 22 May 1501 (A. B. II-III, 3). These documents will be referred to as the 1497 Letter, the 1497 Sonnet, and the Dichiarazione, respectively, in the discussion which follows; they are illustrated as figures thirty-six through thirty-eight. In addition to these, I have personally examined other autograph documents from the period, including two letters from the artist to his brother Buonarroto dated in March 1497 (A. B. IV, 4 and 5), and another letter to his father dated 19 August 1497 (A. B. IV, 2), I am satisfied that the documents to be examined in detail are representative. The Letter and the Dichiarazione are informally written, while the copy of the Sonnet was done with great care and is rather calligraphic in appearance. Examples of letters shown from Tagliente are taken from the section titled "La lettera fiorentina bastarda" in Lo presento libro.

${ }^{41}$ Derolez, 170. 
Michelangelo used numerous letter forms that clearly conform to cursiva or merchantescha models or are otherwise non-cancellarescha in appearance. These include $\mathbf{a}, \mathbf{b}, \mathbf{d}, \mathbf{f}, \mathbf{h}, \mathbf{i}$, double $\mathbf{l}, \mathbf{q}$, long $\mathbf{s}$, and capital $\mathbf{M}$. Cancellarescha forms of these letters do not appear in the 1497 Letter or Sonnet. There is also a curious and possibly idiosyncratic minuscule $\mathbf{g}$ with a long, flowing, and unclosed lower loop which is not found in any of the examples in the writing books of Arrighi, Palatino, or Tagliente. In order to substantiate the merchantescha character of the handwriting, I shall examine each of these in turn.

The single-compartment a from the name "Glionardo" in line seven of the 1497 Letter is written in a single stroke and the ductus and appearance are identical to the form in the word "littera" in the first line of the Florentine example in Tagliente (figure 7).

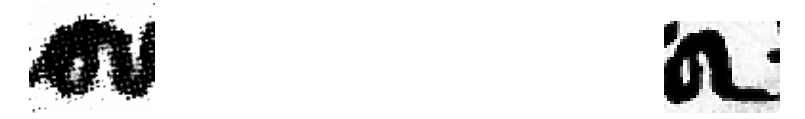

Figure 7. Merchantescha minuscule a from Michelangelo, 1497 Letter, and Tagliente.

Sloping approach strokes are used on the ascenders of $\mathbf{b}, \mathbf{d}, \mathbf{h}$, and $\mathbf{l}$, and this is a characteristic of hybrida script. The examples are from lines five, two, three, and seven, respectively, of the 1497 Letter (figure 8). The $\mathbf{h}$ appears in an abbreviation of "che." These approach strokes disappear in the artist's cancellarescha hand and are replaced by a short thick stroke which approaches the ascender horizontally from the right. The ductus of the $\mathbf{b}$ and $\mathbf{d}$ is similar; the letter begins with the upstroke, turns vertically downward and ends with the loop written clockwise at the end of the downstroke. In the cancellarescha hand the loop is either made separately or is formed counter-clockwise.

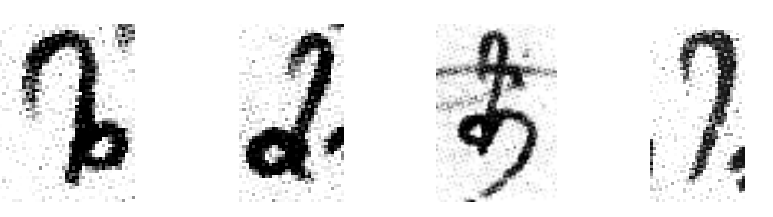

Figure 8. Examples of merchantescha $\mathbf{b}, \mathbf{d}, \mathbf{h}$, and $\mathbf{I}$ from 1497 Letter.

Examples of $\mathbf{f}$ and long $\mathbf{s}$ are numerous, and in merchantescha the two letters should be studied together. As described by Derolez, both have "a remarkably fat and 
pointed form, which has its origin in the cursive ductus, consisting of a downward and upward movement of the pen. In many specimens of more rapid handwriting this ductus is still visible, but in general the space between the two lines was filled up with ink." ${ }^{42}$ Both types are present (figure 9); the former as the initial letter of the word "scultore" the artist's signature in line thirteen of the 1497 Letter. The latter appears in line eleven of the 1497 Sonnet as the penultimate letter in the word "medusa;" also note again the ductus of the minuscule a, identical to the examples above. Two examples of minuscule f, showing a matching ductus, are from line seven of the 1497 Letter and line one of the 1497 Sonnet. It is interesting to note that in the Dichiarazione instances of the use of both
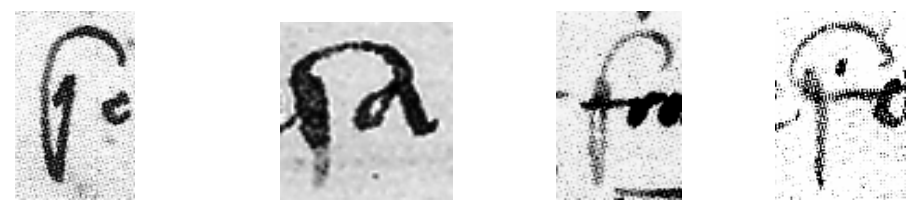

Figure 9. Examples of merchantescha long s and f from 1497 Letter and Sonnet.

the merchantescha and cancellarescha long $\mathbf{s}$ are present. For example, in writing the words "sono soscritto" in line twenty-three, Michelangelo used the merchantescha long $\mathbf{s}$ in the first word and the cancellarescha long $\mathbf{s}$ in the second (figure 10). There is an interesting variation of the ductus of the cancellarescha form in the Dichiarazione, with the downstroke written first, followed by adding the top horizontal stroke afterward; this is clearly visible in the first long $\mathbf{s}$ of "soscritto." The coexistence of these two forms in one document, as well as other characteristic merchantescha and cancellarescha letters,

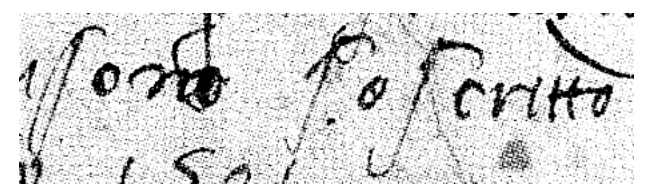

Figure 10. Dichiarazione, line 23, showing merchantescha and cancellarescha long s.

demonstrates that Michelangelo had decided by 1501 to make the alteration in his handwriting, that he was consciously working to change it, and that it was at that point in a transitional stage between merchantescha and cancellarescha. There is no other reason

${ }^{42}$ Derolez, 145. 
for the letter forms of both distinct scripts to appear in the same document. Annotations on drawings show that the change to cancellarescha was complete by 1502 , and after this point Michelangelo's use of merchantescha long $\mathbf{s}$ is rare but not completely absent; for example, it is present in the word "scultore" in the artist's signature of the letter to his brother Buonarroto dated 26 March 1507 (A. B. IV, 10).

The minuscule $\mathbf{h}$ is one of the most distinctive letter forms of Gothic, not only of the merchantescha cursive hand but also in the textualis book hand. It invariably appears with the bowl extending below the writing line, and sometimes has a long graceful loop returning to the next letter. Both types are illustrated by Tagliente, and both were used by Michelangelo in the 1497 Letter and Sonnet (figure 11). The example from the Letter is in the signature in line thirteen, and the example from the Sonnet is from line one in the word "chalici." The merchantescha $\mathbf{h}$ does not appear in the Dichiarazione.
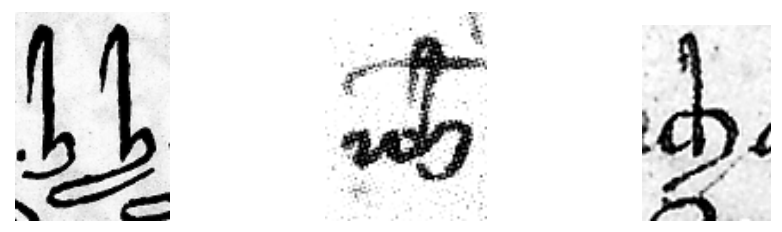

Figure 11. Examples of merchantescha $\mathbf{h}$ from Tagliente, 1497 Letter, and 1497 Sonnet.

Minuscule $\mathbf{i}$ appears as a simple minim, or short vertical stroke, or in its long form resembling modern j. As noted above, it was frequently dotted in Germany and central Europe but not elsewhere, and in Michelangelo's merchantescha handwriting both forms consistently lack dots. The example from the 1497 Letter is from line one, "[al nome] di dio a dj [primo di luglio]" and from the Sonnet, also from line one, "chalicj." Both forms of $\mathbf{i}$ are visible in each example (figure 12). The rule for the use of long $\mathbf{i}$ is that it appears in final position, ${ }^{43}$ as is usual in merchantescha, but also in medial position after $\mathbf{i}, \mathbf{u}, \mathbf{n}$, and $\mathbf{m}$ such as in "meravjliate" in line two and "venjre" in line nine of the Letter, and by itself with an abbreviation mark - not a dot - above it (for " $j n$ ") in line eleven of the Sonnet. Short $\mathbf{i}$ is occasionally dotted in the Dichiarazione, but long $\mathbf{i}$ is nowhere present. Bardeschi Ciulich states that after 1545, the artist often used long $\mathbf{i}$ as the last

\footnotetext{
${ }^{43}$ Bardeschi Ciulich, 16: "La $j$ è di solito in fine di parola o dopo lettera con aste $(i, u, n, m)$ un uso che era piuttosto frequente nei manoscritti per evitare errori di lettura." "The $j$ is usual at the end of a word or after a letter with verticals $(i, u, n, m)$, a use that was rather frequent in manuscripts to avoid reading errors."
} 
letter of his signature ${ }^{44}$ and it can be seen used in this way in a letter dated 28 December 1563 (A. B. IV, 182) to his nephew.
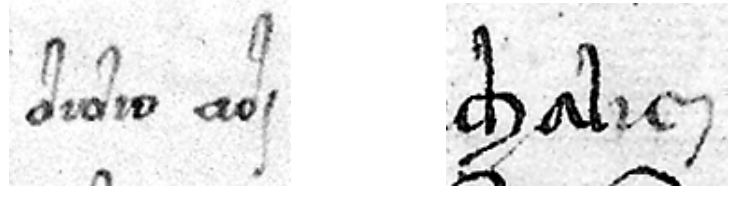

Figure 12. Short and long i from 1497 Letter and Sonnet.

Minuscule $\mathbf{l}$ is written with an approach stroke from the left, as noted above. When double $\mathbf{l}$ appears, the two letters are ligatured together in a distinctively merchantescha manner, which is specifically shown by Tagliente. This ligature, however, appears only in the Letter and in the Dichiarazione where I believe it is related to the cursive ductus written rapidly. The illustration from Tagliente shows double $\mathbf{l}$ without and with the ligature. The next example, without the ligature, is the word "rotelle" from line three of the 1497 Sonnet. The example from the 1497 Letter is from the word "della" in line four, and from the Dichiarazione the word "nella" in line four (figure 13).
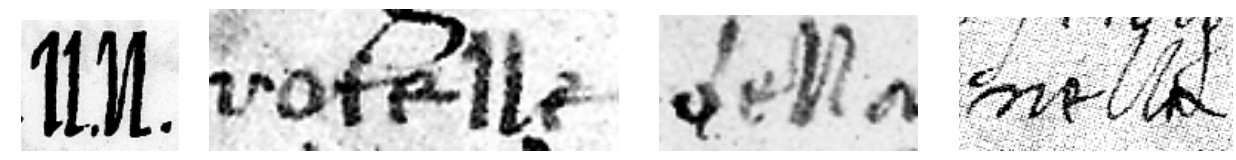

Figure 13. Merchantescha double I from Tagliente, 1497 Sonnet, 1497 Letter, and 1501 Dichiarazione.

In the Sonnet, minuscule $\mathbf{q}$ is consistently written with a straight descender, an attribute which is constant throughout all the examples of merchantescha which appear in the writing manuals. There are three q's in the Letter. All three have a tiny bulbous termination of the descender, and in the one in line four this termination extends very slightly toward the left, a feature found in some cancellarescha models. In the Dichiarazione, however, $\mathbf{q}$ has been changed to one of the two typical cancellarescha forms and the straight-descender form is not present (figure 14).

\footnotetext{
${ }^{44}$ Bardeschi Ciulich, 16.
} 


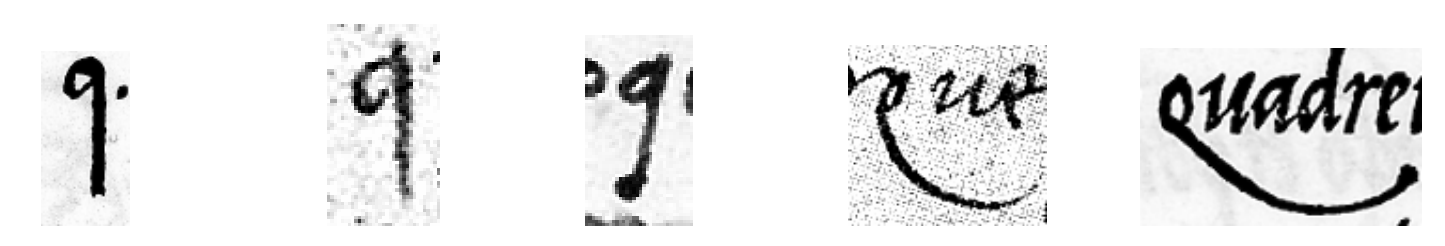

Figure 14. Merchantescha $\mathbf{q}$ from Tagliente, 1497 Sonnet, and 1497 Letter. Cancellarescha $\mathbf{q}$ from Dichiarazione and Arrighi, Operina, 6.

Majuscule $\mathbf{M}$ takes two forms. In the 1497 Sonnet, it appears at the beginning of two lines and has an essentially Roman form, as do majuscule $\mathbf{Q}, \mathbf{S}$, and $\mathbf{V}$, which also appear. In the signature line of the Letter it has a merchantescha form resembling the majuscule $\mathbf{M}$ written by Palatino in the example of "Merchantile Fiorentina" in his Libro nvovo, with a long loop below the writing line extending to the left (figure 15).
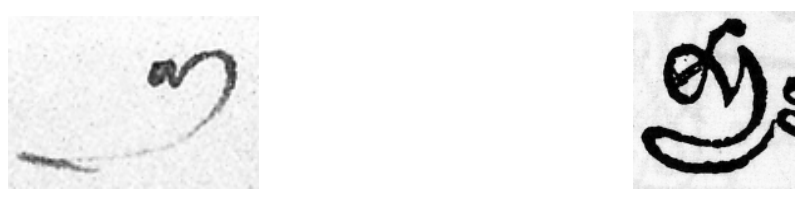

Figure 15. Merchantescha majuscule $\mathbf{M}$ from signature of 1497 Letter and from Palatino.

The $\mathbf{g}$ has an unusual appearance in the Letter, and may be described as neither merchantescha nor cancellarescha. In the Sonnet, it has a form resembling the usual modern minuscule, but with the lower loop sometimes open, as in the 1497 Letter, and sometimes closed. The ductus of the letter in the 1497 Sonnet is that the circular upper loop is formed first, in a clockwise direction, and then the descender is brought down to form a graceful lower loop first to the right and then to the left. In the Dichiarazione, the ductus is similar, but the lower loop begins vertically and its termination resembles cancellarescha models. The appearance of the $\mathbf{g}$ is similar in the annotation to the Sketch for the Bronze David (ca. 1501-2; see below, figure 43). The ductus is clearly different, however, from both the Letter and the Sonnet, and Michelangelo must either have invented the new letter or adopted a new form. In either case, it was necessary for him to unlearn what he had previously been taught, an undertaking which emphasizes the necessity of a specific decision to make the change. The examples of $\mathbf{g}$ are from line six of the Letter, line seven of the Sonnet, line one of the Dichiarazione, and from the annotation on the Bronze David sketch (figure 16). 

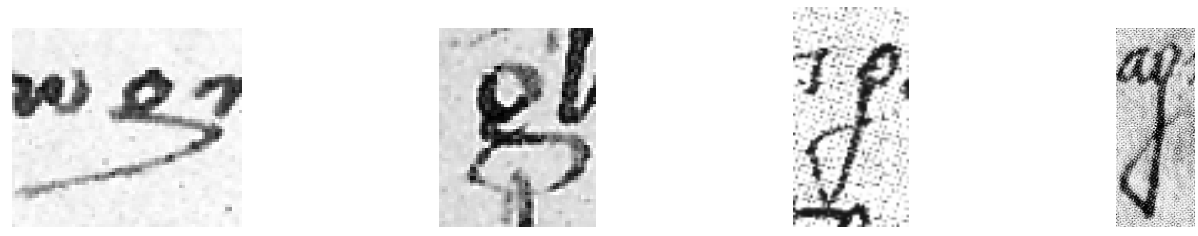

Figure 16. Minuscule $\mathbf{g}$ from 1497 Letter, 1497 Sonnet, 1501 Dichiarazione, and Sketch for the Bronze David.

These are the specific gothic or merchantescha letter forms found in the three documents. With one exception, all of them, including the unusual minuscule $\mathbf{g}$, are also present in the letter of 2 July 1496, which I believe that Ramsden judged incorrectly not to be in Michelangelo's handwriting. The single exception among the letterforms we have examined is that the majuscule $\mathbf{M}$ in the artist's signature in the 1496 Letter is a Roman form.

Additionally, one most important and overarching characteristic of merchantescha must be noted: the general shape of the letters. This attribute is particularly evident in the Sonnet, with its calligraphic execution. Merchantescha letters have a generally round appearance, a cardinal attribute of the script. This trait is specifically identified by Arrighi in Il Modo, in which he states, "[t]he principles of the merchantescha letter, in my opinion, is that they should be made in such a way in which I have designated the whole alphabet below for your example...that all the bodies of such letters have to be made in a perfect square in order that the script may have a round and not an elongated [shape]." 45 This quality of roundness, the construction of the letters within the shape of a perfect square, is one of the primary characteristics that distinguish merchantescha from cancellarescha, in which the letters are formed within an oblong rectangle. A statement by Arrighi in La operina, concerning the cancellarescha letters a, $\mathbf{d}, \mathbf{c}, \mathbf{g}$, and $\mathbf{q}$, explicitly details the manner in which cancellarescha letter forms differ from merchantescha: "they have to be made in an oblong square and not a perfect square in such a way." ${ }^{46}$

\footnotetext{
45 "Li principi de la 1[ette]ra Merchantescha, secondo el parer mio, se debbono fare in tal modo, chome qui sotto $\mathrm{p}$ [er] tuo exemplo ti ho tutto lo Alphabeto designato, Racordandoti, che tutti li chorpi de tal littera se hanno da formare de uno quadro perfetto accio che la scrittura habbia del rotondo et non del longo." 46 "...se hanno da formare in vno quadreto oblongo et non quadro perfecto in tal modo".
} 
The cursive form of the humanistic script was originated by Niccoli about 1420 for his own handwriting. ${ }^{47}$ He developed it to serve practical purposes, namely, for legibility and speed, and not for beauty. The scribes who copied texts for the Humanists and the Humanists themselves were often one and the same. Wardrop states, "[t]he dedicated purpose of the Humanist was not only to rescue from oblivion the texts of classical authors; but to multiply, and later, in the light of new discovery and through the increase of knowledge, to collate and edit them. This function bulked large in the humanists' labours, labours for which a cursive script was the obvious vehicle. The humanistic cursive - the informal neo-caroline script which was to crystallize in the early sixteenth century as the cancellaresca corsiva or italic of the writing-masters - carried preponderantly the commentaries, the interlineations, and the personal memoranda of the humanists. "48 Unlike the gothic textualis and cursiva scripts, there were no ambiguous letter forms in cancellarescha to hinder legibility, and its cursive ductus lent itself to the large amount of writing and copying to be done. We have seen that the upright humanistic book script derived from Caroline minuscule adopted for record keeping in the Apostolic Chancery early in the fifteenth century was replaced by cancellarescha shortly thereafter. After cancellarescha had gained general popularity, its characteristics were regularized by various writing masters. The first to categorize the traits of cancellarescha, as noted above, was Arrighi, who described himself on the reverse of the title page of La operina as "scrittore de breui ap[osto]lici."

We turn to examples from Arrighi's work to compare with Michelangelo's later handwriting. I have chosen Arrighi's work as a standard for cancellarescha both because the Operina was published closest to the time when Michelangelo made the change from merchantescha and because Arrighi's instruction and models are intended more for laypeople. In contrast, the books of Tagliente and Palatino were aimed more toward professional scribes and calligraphers. There is one difficulty, however, in that the examples in Arrighi's work are specifically meant to instruct. More particularly, they are written as models of practical penmanship, while the letters, records of accounts and memoranda written by Michelangelo and available for examination were not. We shall

\footnotetext{
${ }^{47}$ Brown, Guide, 127; Ullman, 59-77.

${ }^{48}$ Wardrop, "Civis Romanus," 18.
} 
examine four representative documents from Michelangelo's later writings to assess his cancellarescha script. The earliest is a private contract with several quarry masters of Carrara commissioning them to supply marble for the tomb of Julius II, dated 10 December 1505 (A. B. II-III, 7). The second and most "calligraphic" is the autograph Sonnet, "I'o gia fatto u[n] gozo" (A. B. XIII, 111), on which the artist included a sketch of himself working on the ceiling of the Sistine Chapel, written between 1508 and 1512 . The third is a neatly written ricordo concerning expenses for the tomb of Pope Julius II, intended for the Papal Chancery, from 1508 (A. B. I, 1). The fourth is a carefully written formal letter to Cardinal Giulio de' Medici from 1518 (A. B. V, 17). These documents will be referred to as the Contract, the 1508 Sonnet, the Ricordo, and the 1518 Letter, respectively; they are illustrated as figures thirty-eight through forty-one. Some examples from annotations on drawings will also be presented. For purposes of clarity and to allow direct comparison, we shall examine the same letters considered for the merchantescha: $\mathbf{a}, \mathbf{b}, \mathbf{d}, \mathbf{f}, \mathbf{h}, \mathbf{i}$, double $\mathbf{l}, \mathbf{q}$, long $\mathbf{s}$, and majuscule $\mathbf{M}$.

Minuscule $\mathbf{a}$ is written as a single compartment letter in cancellarescha as well as in merchantescha. In the Operina, Arrighi gives general instruction as to the shape of the letter conforming to the oblong rectangle and also shows precisely how it is to be written. ${ }^{49}$ He begins by showing the oblong rectangle and demonstrates how the top stroke is to be done between the two upper corners, moving from right to left; then the downstroke, the diagonal upstroke, and the vertical finishing downstroke, ending with a short upstroke leading to the next letter (figure 17). A similar ductus is present in

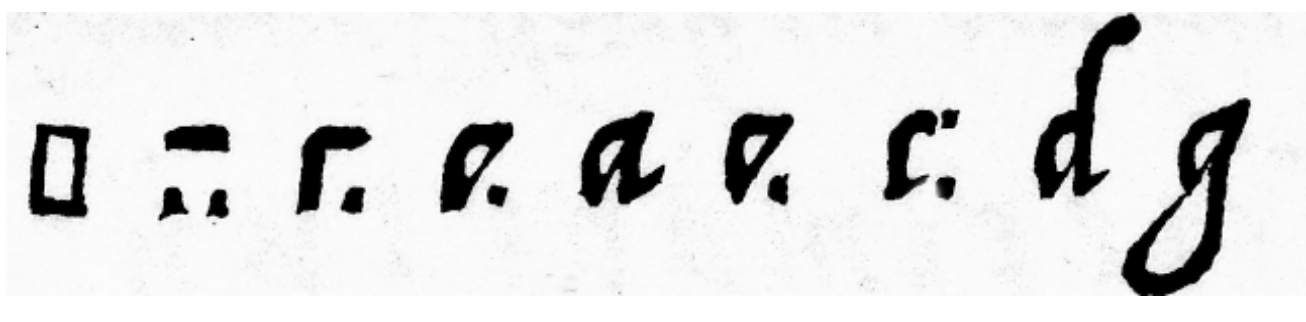

Figure 17. Arrighi, method of construction of cancellarescha minuscule letters. See also figure 43.

minuscule a from line three of the Contract, line five of the 1508 Sonnet, line one of the ricordo, and line one of the 1518 Letter (figure 18). In addition, the same form is present in the word chollarcho inscribed on the Sketch for the Bronze David, dated by Tolnay

${ }^{49}$ Arrighi, Operina, 6. 
between September 1501 and August 1502. ${ }^{50}$ The cancellarescha form as such is not present in the Dichiarazione, though a very few a's show a slight tendency toward the oblong shape.
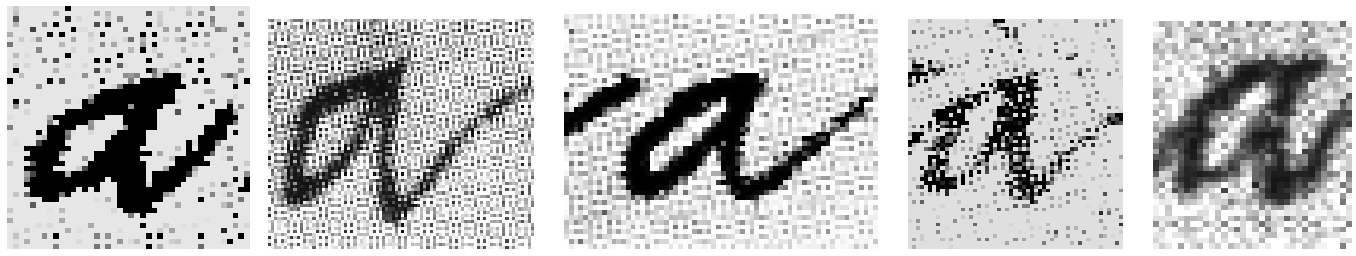

Figure 18. Cancellarescha a from Contract, Ricordo, Sonnet, Letter, and Sketch for the Bronze David.

Cancellarescha minuscule b is generally written with one continuous stroke, ${ }^{51}$ beginning with the thick stroke at the top of the ascender and continuing with the lower loop turning counterclockwise and joining the ascender, whereas the merchantescha $\mathbf{b}$ (see above) was written beginning with an upstroke from the left and ending with a clockwise loop. The example from the Contract is from line three, from the Ricordo from line one, from the 1508 Sonnet from line five, and from the 1518 Letter from line fourteen. The example from the Letter shows a double $\mathbf{b}$ and both have the typical cancellarescha form. The one on the right clearly shows the ductus: the letter begins with the downstroke and finishes at the top of the loop. There is an area of increased opacity produced by a tiny drop of ink left at the end of the stroke as the pen was lifted. Sometimes the letter was made in two strokes, as in line nine of the Ricordo, with the ascender written first and the loop completed with a second stroke (figure 19).
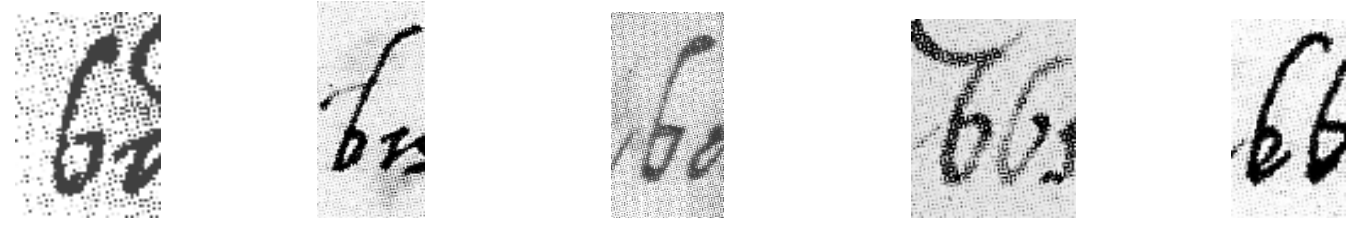

Figure 19. Cancellarescha b from Contract; Ricordo, 1; Sonnet; Letter; and Ricordo, 9.

\footnotetext{
50 Tolnay, 183.

${ }^{51}$ Arrighi, Operina, 14. "Mi é parso al proposito dirti, quali sonno quelle che con uno, quali q(ue)lle con dui tratti se facciano, quelle che con uno tratto se fanno, sonno le infrascritte, cioe a b c b g h i $11 \mathrm{~m} \mathrm{n} \mathrm{o} \mathrm{qr}$ s fu y z Lo resto poi de l'Alphabeto se se fa in dui Tratti d e e f k p t x \& "It seems apropos to tell you, which [letters] are made with one and which with two strokes, those which are made with one stroke, are the ones written below, namely a b c b g h i $11 \mathrm{~m} \mathrm{n} \mathrm{o} \mathrm{q} \mathrm{r} \mathrm{s} \mathrm{fu} \mathrm{y} \mathrm{z;} \mathrm{the} \mathrm{rest} \mathrm{of} \mathrm{the} \mathrm{alphabet,} \mathrm{then,} \mathrm{are} \mathrm{made} \mathrm{in}$ two strokes, d e e f k p t x \&"
} 
Minuscule cancellarescha $\mathbf{d}$ is one of the letters made with two strokes. These consist of the ascender, identical to minuscule $\mathbf{l}$, and the loop, identical to minuscule $\mathbf{c}$. Arrighi shows that the c portion is made first, and the ascender added afterward (see above). In these examples, it can be seen that the c segment of the letters must have been made first since it overlaps the l-shaped ascender and the tail of the ascender is tied to the next letter; otherwise, if the ascender were written first, the loop must be added afterward, an awkward ductus. The examples are from line three of the Contract, lines two and eight of the 1508 Sonnet, from line seven of the Ricordo, and line three of the 1518 Letter (figure 19). The examples from line two of the Sonnet and from the Letter show the upper end of the c portion of the letter overlapping the ascender (figure 20). The merchantescha d was written in one stroke, with the lower loop continuous with the ascender and formed in a clockwise direction, and this ductus is clearly visible in figure 12 above. Rather than adapting the ductus he had learned for $\mathbf{d}$, Michelangelo therefore adopted a new way of writing the letter.
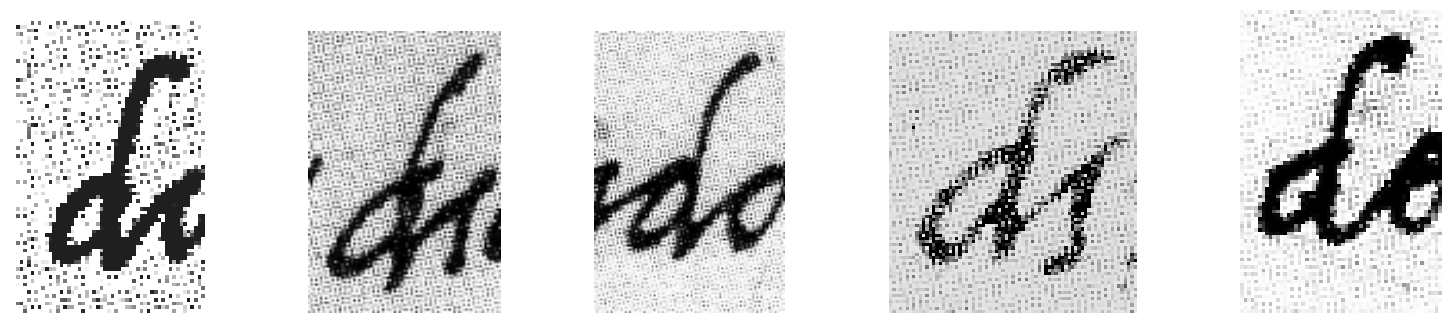

Figure 20. Cancellarescha d from Contract; Sonnet, 2; Sonnet, 8; Ricordo; and Letter.

In contrast to the earlier section on merchantescha, Michelangelo's cancellarescha $\mathbf{f}$ and long $\mathbf{s}$ cannot be examined together. According to cancellarescha models, both should be written beginning with the short flat and thick stroke at the top of the letter moving from right to left, continuing at an angle down and to the left, and finishing with another short flat stroke. This is in contrast to the foot of the $\mathbf{f}$ and of the long $\mathbf{s}$ in the merchantescha hand, which was pointed and vertical and showed no extension to the left. Michelangelo had adopted the basic cancellarescha model for both letters when he wrote the Dichiarazione. By the time he wrote his calligraphic annotation on the Sketch for the Bronze David, he had developed a decorative form of minuscule $\mathbf{f}$ which he continued to use for many years. The ductus of this letter begins 
with a horizontal or slightly angled approach stroke from the left added to the usual form, which otherwise conforms to the cancellarescha appearance. He uses this form also for majuscule F. The examples are from Arrighi, from line ten of the Dichiarazione, from the annotation on the Sketch for the Bronze David, from line seven of the Contract, from line ten of the Ricordo, and from line four of the 1518 Letter where it is used as the initial capital letter in "Fire[n]ze" (figure 21).
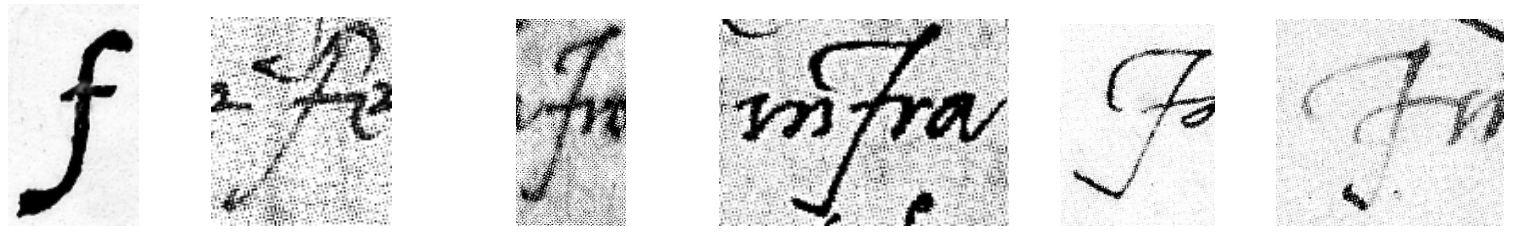

Figure 21. Cancellarescha f from Arrighi, Dichiarazione, Sketch for the Bronze David, Contract, Ricordo, and Letter.

The distinctive merchantescha form of $\mathbf{h}$, in which the bottom of the bowl extends below the writing line, had already been abandoned by Michelangelo by the time he wrote the Dichiarazione and in its place he substituted the typical cancellarescha form. In the Dichiarazione a sloping approach stroke is occasionally present, as in the examples for $\mathbf{b}, \mathbf{d}, \mathbf{h}$, and $\mathbf{l}$ above. In later documents there is at times is a slanting upstroke toward the descender of $\mathbf{h}$ from the left and at times there is the short stroke from the right. Both forms can occur in the same document, but the most important attribute, the characteristic cancellarescha form of the bowl, is always present, while the merchantescha form with its extension below the writing line, never appears. The examples are from Arrighi, line seven of the Dichiarazione, the Sketch for the Bronze David, lines one and seven of the Ricordo, line five of the Contract, and line six of the 1518 Letter (figure 22).
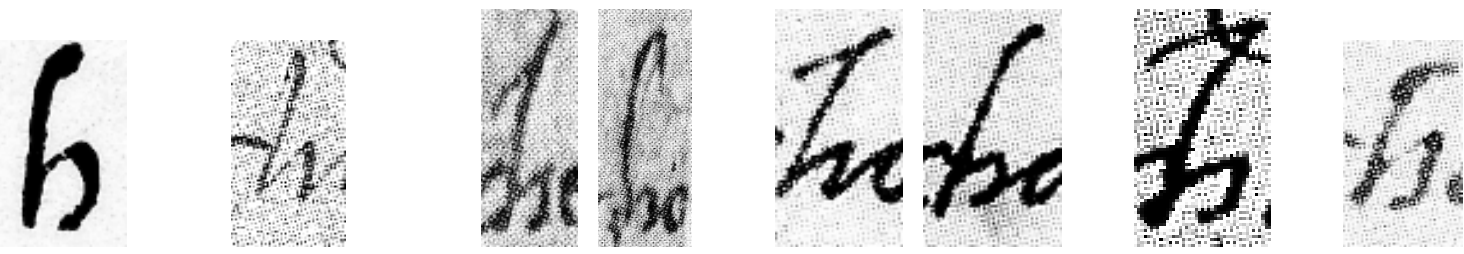

Figure 22. Cancellarescha h from Arrighi, Dichiarazione, Sketch for the Bronze David (2), Ricordo (2), Contract, and Letter. 
Minuscule $\mathbf{i}$ is written as a short vertical stroke, a minim, as in merchantescha, but in the cancellarescha script has acquired a dot. This diacritical mark is not present in the Dichiarazione. The long $\mathbf{i}$ is absent from the Dichiarazione onward except occasionally in the artist's signature, as noted above.

Both single and double $\mathbf{I}$ acquired the beginning stroke from the right, in contrast to the approach stroke from the left present in merchantescha, by the time of the Sketch for the Bronze David, but it still had a slight upward course. This stroke was horizontal in the Contract and subsequent documents and then matches Arrighi's model. There is no ligature between double $\mathbf{I}$ as was sometimes present in merchantescha. The first examples are from Arrighi, showing the method of construction of the letter and the appearance of the unligatured double $\mathbf{l}$. Examples in Michelangelo's handwriting are from the Sketch for the Bronze David, line four of the Contract, line five of the 1508 Sonnet, and line twenty of the 1518 Letter (figure 23).
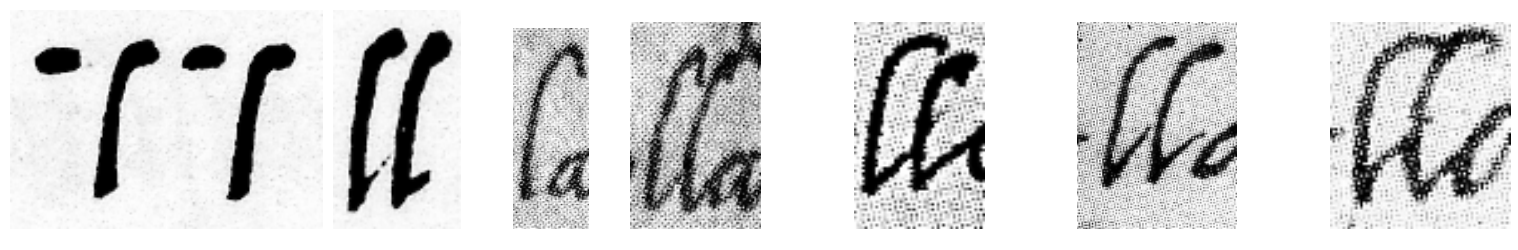

Figure 23. Cancellarescha $\mathbf{I}$ and double $\mathbf{I}$ from Arrighi, Sketch for the Bronze David, Contract, Sonnet, and Letter.

Michelangelo's minuscule q had lost its merchantescha appearance with its straight descender by the time the Dichiarazione was written. Arrighi gives an example of a cancellarescha $\mathbf{q}$ which resembles minuscule $\mathbf{g}$ without the lower loop closed but this form does not appear in the documents under consideration. It is visible in the second line of a Sonnet on the verso of Ashmolean Museum 18, Studies of Horses and a Battle Sketch, but these lines and several others on the same sheet are judged by Barocchi $^{52}$ to have been traced by Michelangelo the Younger (1568-1647; the artist's grand-nephew). The examples are from Arrighi, line two of the Dichiarazione, line six of the Contract, and line three of the 1518 Letter (figure 24).

\footnotetext{
${ }^{52}$ Michelangelo, Drawings, notes for Plate 14.
} 

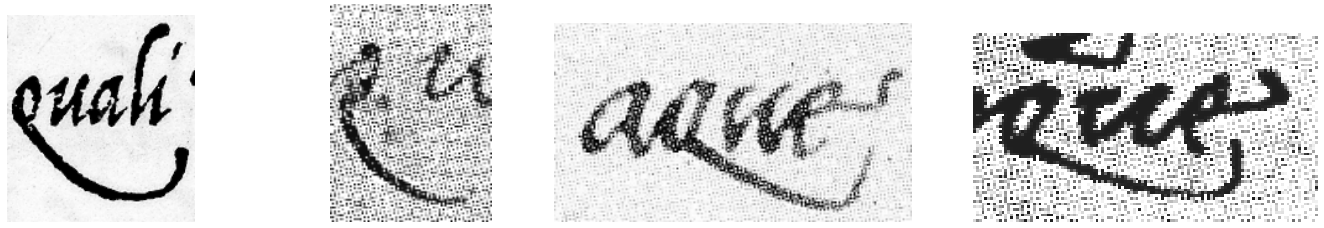

Figure 24. Cancellarescha q from Arrighi, Dichiarazione, Contract, and Letter.

Long s, as previously noted, lost its vertical pointed shape and was replaced by the form described above. The examples are from Arrighi, line five of the 1508 Sonnet and line sixteen of the 1518 Letter (figure 25). There is no long $\mathbf{s}$ in the ricordo, this form having been replaced by short $\mathbf{s}$ throughout. The short round Carolingian $\mathbf{s}$ does not

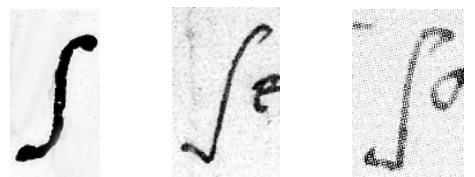

Figure 25. Cancellarescha long s from Arrighi, Sonnet, and Letter.

appear in the 1497 Letter or Sonnet but is present in the Dichiarazione in abbreviations for Monsignore and Signioria. It appears frequently in the Contract and in subsequent documents. Arrighi enjoins his students to make the lower curve of short s slightly larger than the upper, ${ }^{53}$ and this attribute is sometimes present in Michelangelo's handwriting, but is not a constant feature. It would likely be present, however, in a document intended as an example of calligraphy. The examples of short s are from Arrighi, line eight of the Contract, and line six of the 1518 Letter (figure 26).
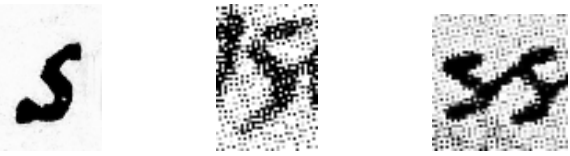

Figure 26. Cancellarescha s from Arrighi, Contract, and Letter.

\footnotetext{
${ }^{53}$ Arrighi, Operina, 11. "Ma perché hauemo due sorte di s come uedi, \& dela lunga te ho insegnato, Resta dire de la piccola, dela quale farai che'l uoltare di sotto sia maggiore che quello di sopra si come vedi signato." "But because we have two kinds of s, as you have seen, and of the long [one] I have taught you, it remains to speak of the small [one], which you should make with the lower curve larger than the one above, as you have seen demonstrated."
} 
Michelangelo's majuscule letters generally follow Roman models both before and after the change in the handwriting, including the 1496 letter, as noted above. The merchantescha capital M present in the artist's signature on the 1497 Letter does not appear after the Sketch for the Bronze David. The examples below (figure 27) from these two documents also demonstrate several more of the marked differences previously described; indeed, there is hardly any letter has the same appearance in both.
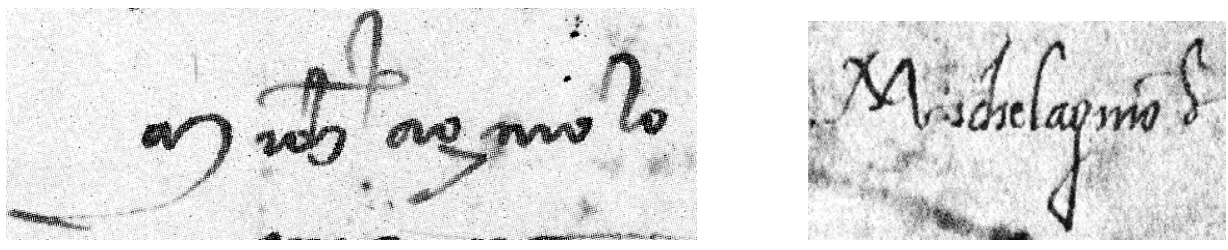

Figure 27. Signatures of the artist from the 1 July, 1497, Letter and the Sketch for the Bronze David.

Several other significant differences between merchantescha and cancellarescha. Many abbreviations were used in cancellarescha, particularly in regard to honorifics commonly used in briefs prepared in the Apostolic Chancery. Arrighi presents an entire page of them in the Operina, and the one used for Reverendissimo can be found in line twelve of the
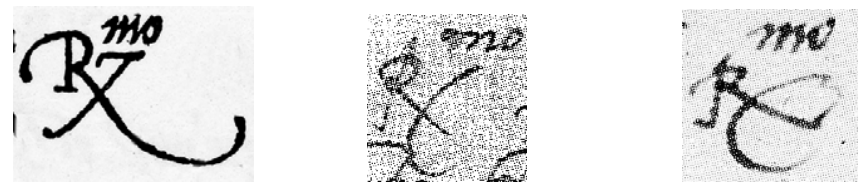

Figure 28. Cancellarescha abbreviation for Reverendissimo from Arrighi, Dichiarazione, and Letter.

Dichiarazione and line one of the 1518 Letter (figure 28). In contrast, Michelangelo wrote the word without abbreviation except for the usual omitted $\mathbf{n}$ and $\mathbf{m}$ marked with horizontal lines in line two of the 1497 Letter (figure 29). Michelangelo's minuscule $\mathbf{x}$

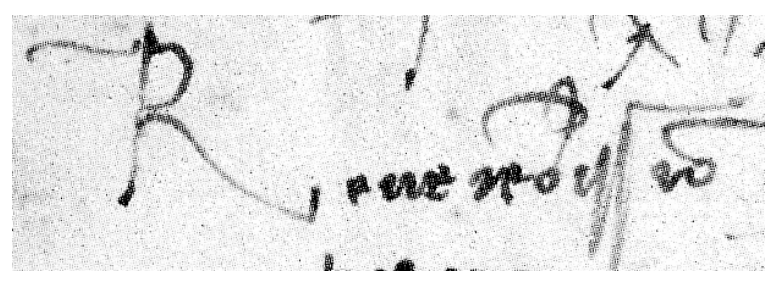

Figure 29. Revere[n]dissi[m]o from 1497 Letter. 
conforms to cancellarescha models but does not occur in the 1497 Letter or Sonnet. Merchantescha minuscule $\mathbf{z}$ occurs in line five of the 1497 Letter and in line fourteen of the 1497 Sonnet, does not appear in the Dichiarazione, and has the modern appearance from the Contract forward. The examples are from the page titled "Il temperare la pen[ $n] a$ ” from the 1525 manual by Celebrino cited above, showing two merchantescha forms of $\mathbf{z}$. Examples from Michelangelo are from the word "sforzare" in line five of the 1497 Letter; from line fourteen of the 1497 Sonnet, showing zz; and the modern form from line one of the 1508 Sonnet (figure 30).
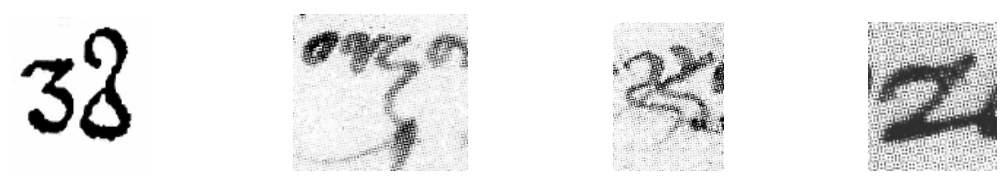

Figure 30. Cancellarescha $\mathbf{z}$ from Celebrino, 1497 Letter, 1497 Sonnet, and 1508 Sonnet.

The most remarkable of all changes in Michelangelo's handwriting after the adoption of the cancellarescha script is his use of the letters $\mathbf{c}$ and $\mathbf{t}$ ligatured together in place of tt. This ligature is part of the early humanistic calligraphic canon ${ }^{54}$ and is present in early cursive examples by Niccoli ${ }^{55}$ where he used it to represent the conventional letters, such as in the words uictu (see above, figure 3) and ductor. Arrighi used it frequently but not exclusively in La operina for tt, and for ct only in a section on permissible ligatures ${ }^{56}$ and in the Latin words cuncta, dilectione, and dictabat. ${ }^{57}$ It does not appear in Arrighi's Il modo nor in the books of Tagliente ${ }^{58}$ or Palatino. In line six of the 1497 Letter, Michelangelo writes "settjmana" with conventional tt, and treats the two letters similarly in the Dichiarazione in the word "eccietto" in line two and "scritta" in line 4 (figure 31). In the Operina, the ct ligature appears in the words tratto, tratti, lettor, and carattheri, among others (figure 32). ${ }^{59}$ In his cancellarescha script, Michelangelo

\footnotetext{
${ }^{54}$ Morison, 36.

${ }^{55}$ For example: Florence, BNCF, Conv. Soppr. I. V. 43, f. 199r; BML 73, 7, f. 3r. Illustrated in Ullman, plates 30 and 32 .

${ }_{56}^{56}$ Arrighi, Operina; 16.

${ }^{57}$ Arrighi, Operina, 28-9.

${ }^{58}$ It is present, however, in Tagliente's supplication to the Doge and Council of Ten of 1491. Venice, State Archive, Cons. x, Misti, filza 5, f. 127. Illustrated in Wardrop, Script, plate 50.

${ }^{59}$ Arrighi, Operina, 14-17.
} 

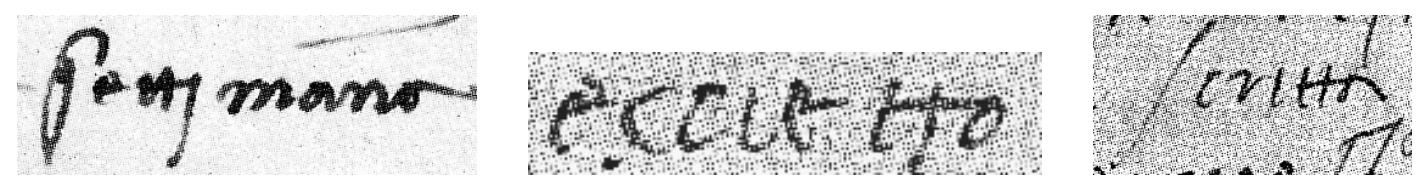

Figure 31. Conventional appearance of tt from 1497 Letter and Dichiarazione.

used it for tt consistently; it appears, for example, in line one of the 1505 Contract ("scritta"), line one of the 1508 Sonnet ("fatto"), and in line nine of the 1518 Letter ("tutta") (figure 33). Bardeschi Ciulich notes that double $\mathbf{t}$ is invariably written as ct. ${ }^{60}$ Milanesi stated in the introduction to the first edition of the letters that he had made a

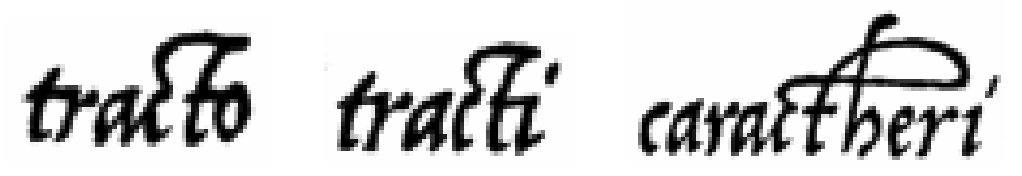

Figure 32. Examples from Arrighi of use of ligatured ct in place of tt: tratto, tratti, carattheri.

number of editorial changes to the texts, and that among these was the alteration of what he believed to be ct to tt. ${ }^{61}$ The use of ligatured $\mathbf{c t}$ for $\mathbf{t t}$ is present in documents written decades later, such as the Four Epitaphs in Honor of Cecchino Bracci (1544; A. B. XIII,
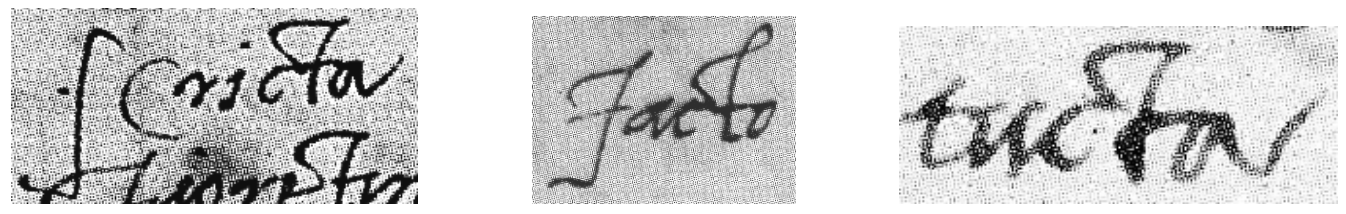

Figure 33. Examples from Michelangelo of use of ligatured ct in place of tt. Contract: scritta; Sonnet: fatto; 1518 Letter: tutta.

33). Further confirmation that the ct ligature was used for tt is found in the Sketch for the Bronze David. The handwritten annotations appear to read, "Davicte cholla fromba e io chollarcho / Michelagniolo / Rocte lalta cholonna el verd..." The last line, as noted by

\footnotetext{
${ }^{60}$ Bardeschi Ciulich, 13. "La doppia $\boldsymbol{t}$ è costantemente rappresentata da $c t . "$

${ }^{61}$ Milanesi, ix. "Io dunque la prima cosa ho sciolto tutti nessi e le abbreviature, levato la $h$, dove era lettera aspirata, mutato il ct nel doppio $t t$, stimando che per questa cambiamento, il suono e il significato della parola rimanga il medesimo." "I therefore in the first place have resolved all combined words and abbreviations, raised the $h$, where there was an aspirated letter, changed $c t$ to double $t$, estimating that for this change, the sound and the meaning of the word remain the same." It is clear, therefore, that Milanesi considered that Michelangelo's use of ct for tt to be a matter of orthography and not calligraphic practice.
} 
Tolnay, ${ }^{62}$ is quoted from Petrarch. It is from Sonnet 269, the first two lines of which are "Rotta è l'alta colonna, e 'l verde lauro, / che facean ombra al mio stanco pensero". Since the initial words in the line by Petrarch must read "Rotte lalta cholonna" the first word in the first line by Michelangelo must necessarily be transcribed not as "Davicte," as it has been almost without exception in the English literature, but as "Davitte." ${ }^{\text {"63 }}$ A definitive confirmation for this transcription is found in the 1568 version of Vasari in the biography of Baccio Bandinelli, wherein he refers to Michelangelo's marble David as "Davitte." 64

Annotations in Michelangelo's handwriting are present on many of his drawings. No complete catalogue of the drawings exists because the attribution of some of them is disputed. No example of the artist's handwriting appears on any of the drawings dated by Goldscheider or Tolnay prior to 1501. Goldscheider cites two drawings which he dates circa 1501 that do contain handwriting. The first is the Sketch for the Bronze David, study for the arm of the marble David and Man digging, nudes seen from the back, studies of shoulders. ${ }^{65}$ The handwriting on these drawings is similar on both sides and is a nearly fully developed cancellarescha. The second is the Study for St. Anne with the Virgin and Child and Nude seen from the back and head studies. ${ }^{66}$ Only one word is legible, "leardo," on the verso of this sheet, and it is written in a script that is identical to that of the Dichiarazione of 22 May $1501 .{ }^{67}$ Since the handwriting likely indicates the date of the drawings, the St. Anne should be dated with the Dichiarazione in1501.

Tolnay has given a possible range for the date of the Sketch for the Bronze David, study for the arm of the marble David between 13 September 1501 and 12 August 1502. These are the dates of the commencement of work on the marble David and the execution

\footnotetext{
${ }^{62}$ Tolnay, 183.

${ }^{63}$ For example, Hughes, in "Lost Poem," correctly transcribes Davitte, 204, but otherwise consistently and incorrectly transcribes ct as ct.

${ }^{64}$ Vasari, 1568. "E nel vero il Davitte di Michelagnolo toglie assai di lode all'Ercole di Baccio..." "And in truth the Davitte of Michelagnolo takes away much of the praise from the Hercules of Baccio..."

${ }^{65}$ Paris, Louvre, INV \#714, recto and verso respectively. The recto is the drawing referred to as the Sketch for the Bronze David above.

${ }^{66}$ Oxford, Ashmolean Museum, 72 recto and verso respectively.

${ }^{67}$ Tolnay believed that this word to be an abbreviation for Le[on]ardo, while Goldscheider was of the opinion that it was leardo (dappled), in both cases referring to the sketch of the bearded man just above it. An extra line is visible above the $a$ and the $r$. It was Michelangelo's practice when using the superscript line to indicate an abbreviation to place this line directly above where the omitted letters should be, and it is therefore unlikely in this word to indicate the omission of the letters on. Goldscheider was probably right.
} 
of the contract for the Bronze David, respectively. The date of the drawing must be nearer the end of the range than the beginning because the handwriting more closely resembles a fully developed cancellarescha than the transitional script of the Dichiarazione. The Man digging, nudes seen from the back, studies of shoulders on the verso should thus also be dated in 1502. Tolnay dates the St. Anne drawing to the spring or summer of 1501; this must be correct because of the similarity of the handwriting with the script of the Dichiarazione. All other annotations on drawings attributed to Michelangelo are either in the cancellarescha script or were written by others. For examples of Michelangelo's cancellarescha script, see particularly Cavalry battle; figure of an apostle; ornament sketches for the tomb of Julius (1505-6), London, British Museum 1895-9-15-496 recto and verso; Sibyl and putto, sketch for the second project for the tomb of Julius (1513), Paris, Louvre R. F. 4112 verso; and Sketch for Christ on the cross (1515), Oxford, Library of Christ Church College C. 13.

In his letters of 1496 and 1497 Michelangelo was still using the perfectly serviceable merchantescha script which was in widespread use and, moreover, which was the standard among professionals and educated persons. Making a radical change in one's handwriting is extremely difficult. We have seen how fundamental the change was, both in learning new letter forms and discarding the ones he had been taught. Making such an alteration requires a conscious determination, which in turn entails commitment, perseverance, and weeks and months of practice; practice not only to learn the new letter forms and the method of writing them, but also for the even more difficult task of unlearning the method one was originally taught. The ductus for many letters and their forms are so essentially different between the two scripts that one is obliged to conclude that there must have been a definite decision by Michelangelo to alter his handwriting. The new script is not, as has been stated elsewhere, an evolution or phase of the old script. ${ }^{68}$ The pedigree of merchantescha, the gothic mercantile cursive, is: Caroline minuscule to protogothic to gothic textualis to gothic cursive or bastarda to

\footnotetext{
${ }^{68}$ Bardeschi Ciulich, 20: "Le numerose lettere al padre e al fratello dal 19 dicembre 1506 al 21 dicembre 1507 documentano in modo esauriente una seconda fase della grafia giovanile, nella quale si sono già affermati i tratti caratteristici della sua scrittura." "The numerous letters to his father and brother from 19 December 1506 to 21 December 1507 document exhaustively a second phase of the youthful writing, which had already affirmed the characteristic traits of his script." On the contrary, the script in a representative letter from Michelangelo in Bologna to his brother Buonarroto in Florence dated March 26, 1507 (A. B. IV, 9) shows characteristics of cancellarescha.
} 
merchantescha. The pedigree of the artist's new script, chancery cursive: revival of Caroline minuscule as humanistic book script by Poggio, in order to replace gothic textualis and cursive; to humanistic cursive as invented by Niccoli; to cancellarescha. The contention that Michelangelo's new script is a development of the old cannot be true. As I have shown, since the two scripts come from different branches of the development of handwriting, such a development is evolutionally impossible (figure 34).

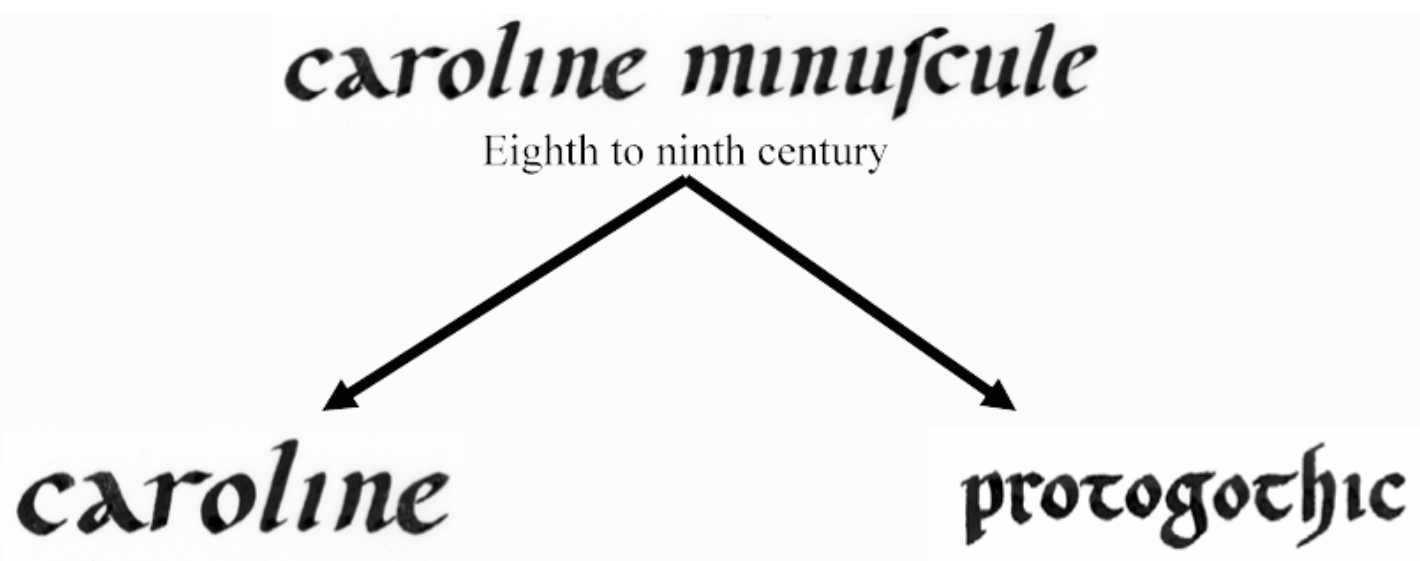

Caroline minuscule revival, fourteenth century

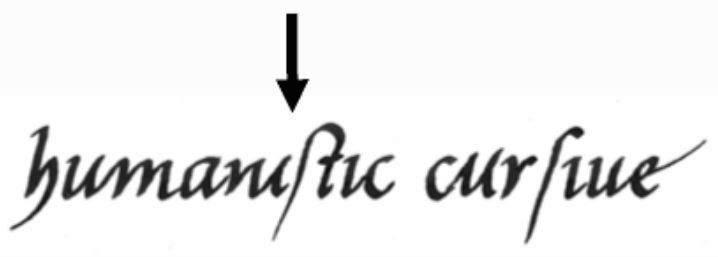

After Niccoli, fifteenth century

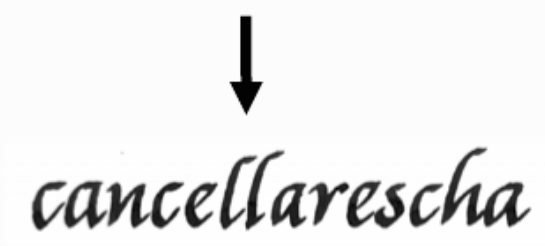

Fifteenth to sixteenth century
Eleventh century

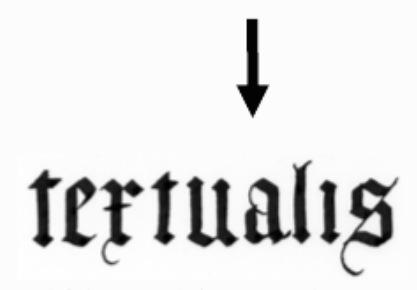

Twelfth to thirteenth century

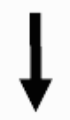

ba/tarda

Fifteenth century

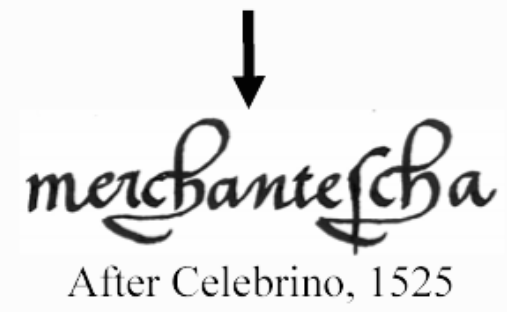

Figure 34. Abbreviated family tree of scripts showing descent of merchantescha and cancellarescha. 


\section{Chapter 4: The Stimulus for the Change}

It is clear from the evidence presented that Michelangelo made a definite decision to alter his handwriting, and so we must now ask how this alteration happened and why. Michelangelo had had contact with people who were promoters and practitioners of the new humanistic cursive hand. According to Condivi, when Michelangelo was between fifteen and sixteen years old, he went to live in the home of Lorenzo the Magnificent. This occurred after his apprenticeship with Ghirlandaio, when he was between fifteen and sixteen years old, ${ }^{69}$ that is, between March 1489 and March 1490; and he stayed until Lorenzo died in 1492. The art collection in the Palazzo Medici during the rule of Lorenzo was extensive, including paintings, sculpture, silver and gold, and books. The palace was filled also with "distinguished people, the constant company in which that house flourished and abounded." ${ }^{, 70}$ It was here that Michelangelo acquired "part of the network of patronage which was to shape a good deal of his career."71 These distinguished people included other patrons of the arts, artists, scholars, and renowned Humanists. They included Angelo Poliziano, tutor to Lorenzo's children; Cristoforo Landino, whose Neoplatonic treatise on Virgil was published in 1480; Marsilio Ficino, commentator on Plato; and the influential Neoplatonist Pico della Mirandola. Michelangelo was acquainted with Landino's commentaries on Dante, and it is very probable that he was familiar also with the works of Ficino and Pico and knew them personally. As Tolnay has stated, "This inspiring group served as a sort of spiritual fount to Michelangelo. To them he owes his concept of esthetics, which is based on the adoration of earthly beauty as the reflection of the divine idea; his ethics, which rests upon the recognition of the dignity of mankind as the crown of creation; his religious concept, which considers paganism and Christianity as merely externally different manifestations of the universal truth."72 In short, the Neoplatonic and Humanistic intellectual milieu of the court of Lorenzo was the source of Michelangelo's world view

\footnotetext{
${ }^{69}$ Condivi, 13.

${ }^{70}$ Condivi, 13.

${ }^{71}$ Hughes, Michelangelo, 22.

72 Tolnay, 18.
} 
at the time of his departure from Florence and his subsequent stays in Bologna, Venice, and Rome, and it remained a source of inspiration to him.

The influence of the Humanists in contemporary intellectual life cannot be overestimated. They "occupied the leading positions in the chanceries of the Papal Curia, of the Florentine Republic, and of many other states and cities, as well as in the councils of princes and republics.",73 Men with humanistic sympathies acted as "chancellors or secretaries to eminent personages [such as] Popes, cardinals and bishops, emperors, kings, princes, and republics" ${ }^{, 44}$ and their official duties included copying official documents and correspondence. For example, the scholar Pietro Bembo (1470-1547), Michelangelo's contemporary, became a secretary to Leo X after having spent some time at the court of Ferrara, and he wrote an elegant humanistic cursive. A significant quantity of these official documents would have been produced in humanistic script, which helped in the dissemination of the script. The Humanists were the professional representatives of the five humanistic disciplines: grammar, rhetoric, poetry, history, and moral philosophy. Their "main object ... was to discover new classical texts, to improve known texts, and to disseminate their discoveries."75 They "wished above all to revive classical Latin culture."76 Indeed, according to Kristeller, Renaissance humanism may be defined as "that broad concern with the study and imitation of classical antiquity which was characteristic of the period and found its expression in scholarship and education in many other areas, including the arts and sciences."77 As we know from the evidence of treatises on education, handwriting formed a portion of the discipline of grammar. The Caroline minuscule that was revived as the humanistic book script was thought at the time to be very ancient. "They [the humanists] also introduced the humanist script... by imitating the Carolingian minuscule, which they mistakenly held to be that of the ancient Romans; and they created the humanistic cursive, which is the basis of our italic script."78 This revival of classical Latin culture extended to art, though humanistic emphasis lay not

\footnotetext{
${ }^{73}$ Kristeller, Eight Philosophers, 19.

${ }^{74}$ Kristeller, "Humanism," 115.

${ }^{75}$ Morison, 34.

${ }^{76}$ Grafton, "Quattrocento Humanism," 23.

${ }^{77}$ Kristeller, "Humanism," 113.

${ }^{78}$ Kristeller, Eight Philosophers, 20.
} 
so much on the art as on the artist. The character of the artist was the more important, for the "ideal of the perfect artist depended on the classical model of perfection."79

Of all the people at Lorenzo's court, the one with the greatest direct influence on the young Michelangelo was Angelo Ambrogini (1454-94), who took the name il Poliziano from his home town of Montepulciano. Poliziano was a polymath: Humanist, poet, classical scholar, philologist, philosopher and one of the first persons ever to practice textual criticism. He lived at the palace of Lorenzo de' Medici, who made him tutor to his children and was in residence during the two to three years Michelangelo was there. According to Condivi, he "loved [Michelangelo] very much and, although there was no need, he continually urged him on in his studies, always explaining things to him and providing him with subjects." ${ }^{, 0}$ Condivi says that he even suggested the subject of The Battle of the Centaurs (c. 1492, Casa Buonarroti, Florence). The degree of influence exerted by Poliziano on the young artist was enormous. It is likely that Poliziano was responsible for Michelangelo's education and that he was in Poliziano's immediate care. ${ }^{81}$ Moreover, “[w] hereas the Neoplatonic thinkers contributed to Michelangelo's notions of order, beauty and grace, the poet Poliziano contributed to his notion of style, and closely related to this, defined his relation to the ancient and modern past." ${ }^{\prime 82}$ The influence of Neoplatonic ideas was especially important, particularly since the artist was in frequent if not daily contact with some of the leading Neoplatonists of the age.

One of Poliziano's greatest contributions to philology arose directly from his relation to the ancient past; namely, textual criticism. The classical literary works which had survived from antiquity, one of the chief interests of the Humanists, had been subject to corruptions and contained many errors. Mistakes made in copying were carried forward by subsequent copyists and Poliziano found it essential to find texts as old as possible in order to determine the correct language and restore ancient works to their original content. To do this, and to avoid having to correct texts by guesswork, he went back to the oldest manuscripts. ${ }^{83}$ It was thus necessary that he acquire facility in the field of paleography so that he could read the books and then copy and correct the passages

\footnotetext{
${ }^{79}$ Cast, 433-4.

${ }^{80}$ Condivi, 15.

${ }^{81}$ Summers, 242-3.

${ }^{82}$ Summers, 243.

${ }^{83}$ Grafton, Scaliger, 27.
} 
where errors appeared. Poliziano demonstrated this ability in Section 46 of his Miscellaneorum, titled "Cacoethes apud Iuvenalem tetrasyllabon, non cacethos." In this section, he suggested that the word "cacethos," which appeared in a standard copy of Satyra VII of Juvenal available to him, be emended to the four syllable word "cacoethes." ${ }^{\prime 44}$ In the course of his brief discussion in support of this emendation, he stated that he found the incorrect word in an old book in Lombardic (also known as Beneventan) script. ${ }^{85}$ Lombardic was a script current from the mid-eighth century to the end of the twelfth century in Italy and which resembles a hybrid of uncial and protogothic. Had Poliziano not known his paleography, he could not have identified the script, understood its position in the evolution of scripts, known whether this or indeed any particular manuscript was older than another, nor been able to fix the location where the book in question had likely been copied. Poliziano's skill in the explication of ancient texts demonstrates his ability as a paleographer. We should also note that Poliziano himself wrote an elegant humanistic cursive with some unusual features such as seriffed p's and q's and a tall medial g (figure 35). Indeed, Poliziano's handwriting

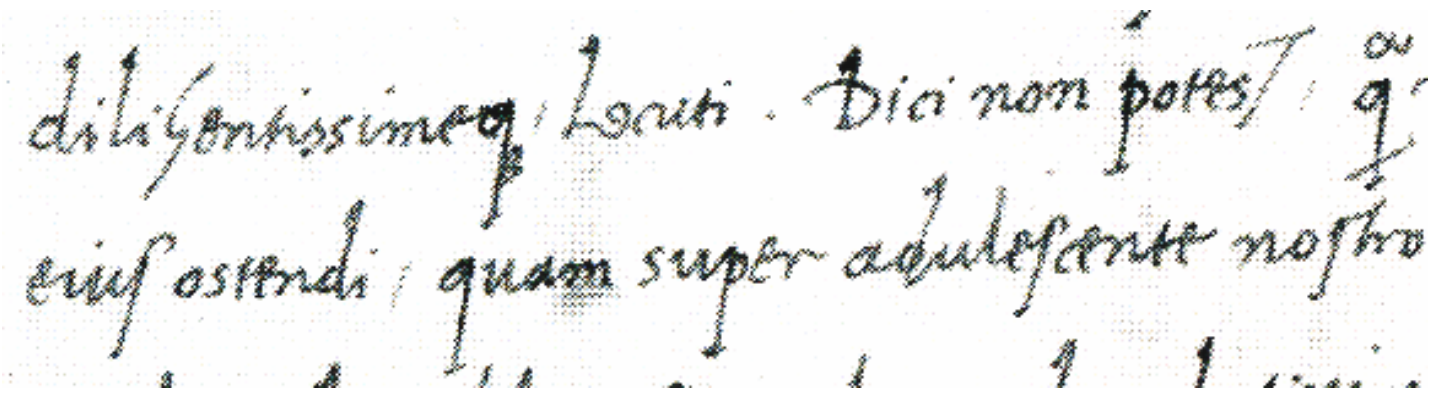

Figure 35. Humanistic cursive handwriting of Angelo Poliziano. ${ }^{86}$

was likely Michelangelo's first significant exposure to the humanistic cursive. The originator of the humanistic cursive hand, Niccolò Niccoli, had been a member of the circle of Lorenzo's grandfather Cosimo. The books that belonged to Niccoli which later became the foundation of the Biblioteca Medicea Laurenziana would have been available

\footnotetext{
${ }^{84}$ Lines 50-52: "Nam si discedas, laqueo tenet ambitiosi / consuetudo mali, tenet insanabile multos / scribendi cacoethes et aegro in corde senescit."

${ }^{85}$ Poliziano, "Miscellaneorum 46," in Omnia opera: "Quod item in uetusto codice langobardis exarato literis rep[er]imus..." "Which likewise we discovered in an ancient book, written in Lombardic letters..."

${ }^{86}$ Poliziano, autograph letter to Giovanni Lorenzi. Rome, Biblioteca Apostolica Vaticana, Vat. lat. 5641, f. $4 \mathrm{r}$ (detail). Illustrated in Supino, 242, plate 1. "diligentissimeq[ue] Locuti. Dici non potest q[uam] / eius ostendi quam super adulescente nostro..."
} 
to Michelangelo, and not only these books, but also many others written in both the humanistic book hand and in the cursive script that evolved into cancellarescha ${ }^{87}$

Michelangelo continued to have contact with Humanists after he left the palace of Lorenzo. His stay in Venice in 1494 is probably so short that it is not important in this connection. He soon returned to Bologna, where he stayed a little more than a year, and his benefactor and patron during his time there was Gianfrancesco Aldrovandi (d. 1512), a member of a distinguished patrician family. Aldrovandi was a patron of literature and a poet. From his habit of having Michelangelo read aloud from Dante, Petrarch, and Boccaccio, ${ }^{88}$ it is likely that he was a Humanist also and that through him Michelangelo would have encountered other Humanists in the city. Michelangelo returned to Florence at the end of 1495, where he remained until June of 1496 . While there he would certainly have renewed his acquaintance with Humanists at the court of Lorenzo di Pierfrancesco de' Medici (1463-1503), and may even have resided at the palace.

\footnotetext{
${ }^{87}$ Vespasiano da Bisticci, a Florentine bookseller, delivered, at Cosimo's direction, two hundred volumes in twenty-two months that had been written under his direction by forty-five scribes (Burckhardt, 132), and these would certainly have been in humanistic script.

${ }^{88}$ Condivi, 19.
} 


\section{Chapter 5: Rome, and the Decision to Change the Handwriting}

When Michelangelo went to Rome in 1496, he carried with him letters of introduction from Lorenzo di Pierfrancesco de' Medici, one of which was to the Cardinal San Giorgio, Raffaele Riario Sansoni (1460/1461-1521). At that time, Riario was among the richest of all the members of the clergy, had a large household, and was a famous collector of antiquities. Riario was a Humanist by temperament and had been "in close contact since his early youth with the great Humanists of the time." ${ }^{89}$ He promoted classical literature, including the plays of Plautus and Terence. He had a personal friendship and correspondence with Erasmus of Rotterdam (1466-1536) ${ }^{90}$ and knew him well enough to open a letter to Erasmus with, "Most illustrious sir, and my particular friend, greeting." 91 Riario had built a magnificent palace which in its architecture recalled imperial Rome, and it was later to become the Palazzo della Cancelleria. Michelangelo lodged with him there from 1496 until 1501. Though the Papal court was the hub of the intellectual life of the city of Rome, Michelangelo appears to have had little direct contact with it at this time. ${ }^{92}$ Still, he would have known of it and its activities through Cardinal Riario. The new humanistic cursive handwriting had been adopted by the Apostolic Chancellery for the production of briefs by 1462, and Michelangelo would have seen it everywhere during his residence in Rome, in official correspondence, books, and briefs and in other official documents, but as I have shown, this would not have been his first acquaintance with the script. The evidence of the transitional script of the Dichiarazione of 1501 and the nearly fully developed cancellarescha annotations on drawings as early as the Sketch of the Bronze David from

\footnotetext{
${ }^{89}$ Frommel, 39-65.

${ }^{90}$ Erasmus, Correspondence, 86 and 94. In Letter 333 to Riario, dated 15 May 1515, in excuse for what he describes as a long silence, "it is not that I have forgotten what I owe you, for I have never ceased to remember and to speak of that, and never shall." In Letter 334 to Cardinal Grimani, also dated 15 May 1515, referring probably to a visit in mid-1509, "whenever I bethink me of the remarkable favour shown me by other cardinals, and especially by his eminence of Nantes, The most cordial encouragement of the cardinal of Bologna, and from the cardinal of San Giorgio not merely encouragement but generosity quite out of the common; above all, that most promising conversation with your Eminence - all this makes me feel that no fortune could possibly fall to my lot generous enough to wean my heart from its longing for the Rome which I once tasted."

${ }^{91}$ Erasmus, Opus epistolarum, 2:117: "Clarissime vir, amice singularis, salutem."

92 Tolnay, 27.
} 
1501 or $1502^{93}$ shows that the artist must have made the decision to change his handwriting while he was staying with Cardinal Riario. The influence of or instruction by any specific person is unknown and unknowable, and it is tempting to speculate that Michelangelo could have been acquainted at this time with Arrighi, his exact contemporary. Apart from his birth year, however, nothing whatever is known with certainty about Arrighi until 1510. The two of them did agree on one artistic point - the value of the judgment of the eye. In the Bondanella translation, Vasari stated that it was Michelangelo's opinion that "it was necessary to have a good eye for measurement rather than a steady hand, because the hands work while the eyes make judgements," ${ }^{94}$ while in the Operina Arrighi stated, at the end of a section on line and letter spacing, "[b]ut because you will maybe find it impossible to keep this rule, if so, strive to take counsel with your eye, and to satisfy it; thus you will achieve the best measure." ${ }^{95}$ Vasari states that during his time in Rome the cardinal "did not give Michelangelo anything to do"96 and he would have been able to find the time required to practice his new handwriting. In the letters to Lorenzo di Pierfrancesco dated 2 July 1496 and to his father on 1 July 1497, Michelangelo used the gothic merchantescha script. In the Dichiarazione he used a combination of merchantescha and cancellarescha letter forms. But the cancellarescha annotation on the Sketch of the Bronze David shows such elegance and such an easy and confident flow and uniformity of the letters, as well as calligraphic touches such as the ct ligature for $\mathbf{t t}$ (discussed above), and the horizontal extension on the $\mathbf{e}$, that since the writing of the Dichiarazione he has clearly practiced a great deal.

There are several possibilities which could explain the change that Michelangelo decided to make in his handwriting while in Rome, including that he made the alteration simply because the appearance of the cancellarescha pleased him and he admired its legibility. To him, however, the gothic mercantile script he had learned in school would

\footnotetext{
${ }^{93}$ Tolnay, 183. "The sketches may have been executed ca. September 13, 1501, when Michelangelo began work on the marble David, and August 12, 1502, the date of the contract for the bronze David." On the verso of this leaf are a study of a nude man in the act of digging, two busts seen from behind, and a study of a shoulder, judged by Tolnay as "stylistically identical with the Oxford drawings" and which he dates ca. 1501. There is also an inscription on the verso in Michelangelo's cancellarescha hand.

${ }^{94}$ Vasari, 1991, 472.

${ }^{95}$ Arrighi, Operina, 19. "Ma perché seria quasi impossibile seruare questa regola, te sforzarai di consigliarti con l'occhio, et a quello satisfare, il quali ti scusara bonissimi compasso."

${ }^{96}$ Vasari, 1991, 424.
} 
have been perfectly legible. It was, moreover, the standard of the time. I believe that personally motivated changes made in handwriting after childhood reflect changes in aesthetics and the maturation of the personality. I believe also that his adoption of the new script was due primarily to the influence of Humanism and, in lesser measure, to his familiarity with and youthful enthusiasm for the philosophy of Neoplatonism. I have shown that Michelangelo was personally acquainted with some of the outstanding proponents of both Humanism and Neoplatonism at the court of Lorenzo the Magnificent. At that court "there would have been other family members and guests, including the Neoplatonic philosophers who were part of Lorenzo's circle. There must have been a heady atmosphere of political power and intellectual performance, especially for Michelangelo, who seems to have learned only a few phrases of Latin." ${ }^{97}$ Michelangelo owed his interest in the classical aspects of Art to Humanism, but it was to Neoplatonism that he owed his concept of aesthetics based on earthly beauty as a reflection of the divine. Tolnay stated, "Michelangelo, like the rest of his generation, also turned away from the external realism of the fifteenth century, but the world to which he aspired was not one of perfected appearances but 'true reality." "98 It is certain that Michelangelo came into contact with Marsilio Ficino (1433-99), the first developer of the Humanist concept of Neoplatonism, at the palace of Lorenzo de' Medici.

The interest of the Humanists in antiquity began in earnest in the fourteenth century though it was foreshadowed in literature and sculpture in the twelfth and thirteenth. According to Burckhardt, ${ }^{99}$ its earliest expression in writing is found in Fazio degli Uberti's book Dittamondo of about 1360. Dittamondo is an account of mystical journeys including one to Rome, which, personified by an old woman, describes her magnificent past. In a work of 1430 entitled Ruinarum Urbis Romae Descriptio, the same Poggio Bracciolini who reintroduced Caroline minuscule as the humanistic script described in detail the ruins of the ancient city. Interest in Italy's classical past increased during the fifteenth century. Particular attention was paid to the books of antiquity, which were thought to be the sources of all human knowledge. Plato's books were included in this group, of course, as were commentaries on them, and classical works

\footnotetext{
${ }^{97}$ Hartt, 502.

98 Tolnay, 64.

${ }^{99}$ Burckhardt, 124.
} 
were emphasized in schools. Michelangelo's interest in the past had been inculcated by the Humanists with whom had come into contact, and this interest was of the highest importance to him. Burckhardt wrote of the culture of antiquity of the Renaissance that "the enthusiastic devotion to it, the recognition that the need of it is the first and greatest of all needs, is nowhere to be found in such a degree as among the Florentines of the fifteenth and the early part of the sixteenth centuries." ${ }^{100}$ The representatives of this culture were the Humanists.

${ }^{100}$ Burckhardt, 146. 


\section{Chapter 6: Conclusion}

Michelangelo's decision to discard the merchantescha script and adopt the cancellarescha occurred at a point between 1497 and 1501. Tolnay informed us that this was a time when "[t]he passive figures of his youth give way to a new heroic race. They no longer seem the victims of forces beyond their control but with strength and resolution are now masters of their own destiny. The period represents a climax in Michelangelo's rationalistic tendencies; the works produced represent his classical style."101 The popularity of the classical style in sculpture was a consequence of the humanistic interest in antiquity, and it is likely that Michelangelo's interest in the classical style was reflected in an interest in the written letter. For example, it is significant that the inscription on the Pietà in St. Peter's in Rome (1498-99) is in the classical Roman majuscule alphabet that had been reintroduced into Florentine sculpture in the early fifteenth century by Mantegna and Ghiberti, among others, ${ }^{102}$ and not in the formal gothic textualis script then current.

In summary, Michelangelo was in contact with some of the most eminent Humanists, scholars, and artists of the Renaissance during his residence at the court of Lorenzo the Magnificent, particularly and most importantly the philologist, textual critic, and paleographer Poliziano. His contact with Humanists continued throughout his time away from Florence, from his departure from Florence after Lorenzo's death until his return to the city in 1501, and he maintained this contact for the rest of his life. The combination of the influences of the disciplines of Humanism, the culture of antiquity, and of the revival of Platonism produced the concept of antiquity as "a sort of ideal existence which could be reconstructed in imagination."103 The Caroline minuscule script that was chosen for revival as a book hand by Coluccio, reintroduced by Poggio, and subsequently modified by Niccoli into a cursive form, was thought at the time to have a very ancient origin. Michelangelo was continually exposed to this script and its

\footnotetext{
101 Tolnay, 93.

${ }^{102}$ Meiss, 98. The models for the humanistic reform of handwriting "were all judged by the early Quattrocento to exemplify lettere antiche. The capitals developed by [the] humanists have a delicacy, attenuation and simplicity that may be compared with early Quattrocento forms in sculpture or architecture."

${ }^{103}$ Blunt, 43.
} 
cursive variations beginning with the time of his arrival at the court of Lorenzo. At some point between 1497 and 1501, he made the decision to alter his handwriting from the merchantescha he had learned at school in Florence to the humanistic cancellarescha.

The time when Michelangelo made this alteration is the precise time that the humanistic qualities of classicism began to emerge in his art, and the concurrence cannot be a coincidence. 


\section{Appendix}

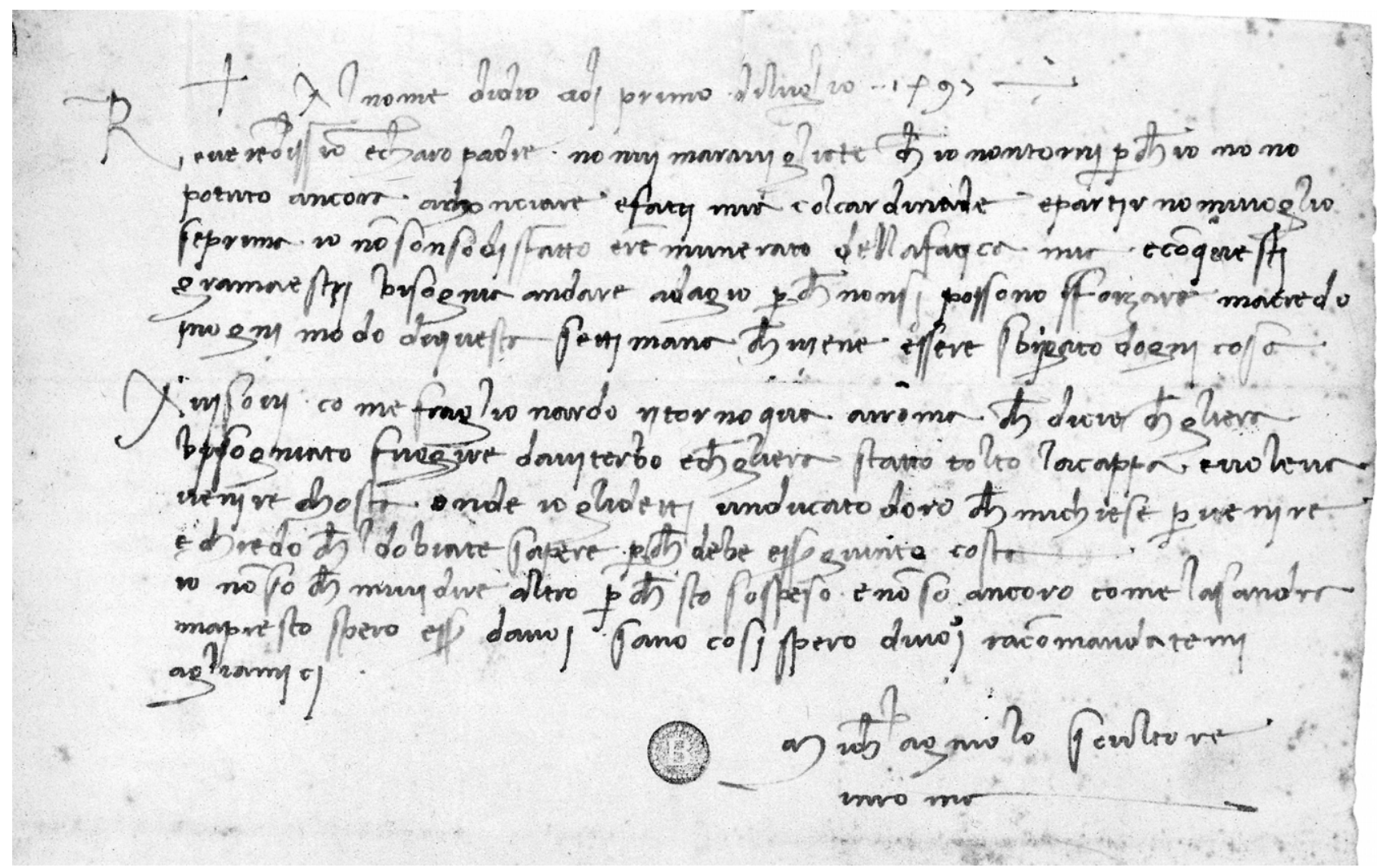

Figure 36. Michelangelo, autograph letter dated 1 July 1497 (detail). Archivio Buonarroti, IV, 1.

+ Al nome di dio a dj primo di luglio 1497.

Reverendissimo e charo padre no[n] mi maraujgliate ch[e] io non tornj $\mathrm{p}[\mathrm{er}] \mathrm{ch}[\mathrm{e}]$ io no no potuto ancora achonciare e fattj mia col cardinale e partjr no mi uoglio se prima io no[n] son sodjsfatto e remunerato della fatjca mia e co[n] questj gramaestrj bisognia andare adagio $\mathrm{p}[\mathrm{er}] \mathrm{ch}[\mathrm{e}]$ non sj possono sforzare ma credo jn ogni modo di questa settjmana ch[e] ujene essere sbrjgato dognj cosa

Aujosuj come fra glionardo rjtorno qua anima qua a roma ch[e] dicie ch[e] gli era bjsogniato fuggire da vjterbo e ch[e] gli era statto tolto la cappa e uoleua venjre chosta onde io gli dettj un ducato doro ch[e] mi chiese $\mathrm{p}[\mathrm{er}]$ uenjre e chredo $\operatorname{ch}[\mathrm{e}] 1$ dobiate sapere $\mathrm{p}[\mathrm{er}] \mathrm{ch}[\mathrm{e}]$ debe e ess[er] giunto cosa

Io no[n] so ch[e] mi uj dire altro $\mathrm{p}[\mathrm{er}] \mathrm{ch}[\mathrm{e}]$ sto sospeso e no[n] so ancora come la sandra ma presto spero ess[er] da uoj sano cosj spero di uoj rac[c]omandatemj agli amjcj

Michelangiolo scultore in roma 


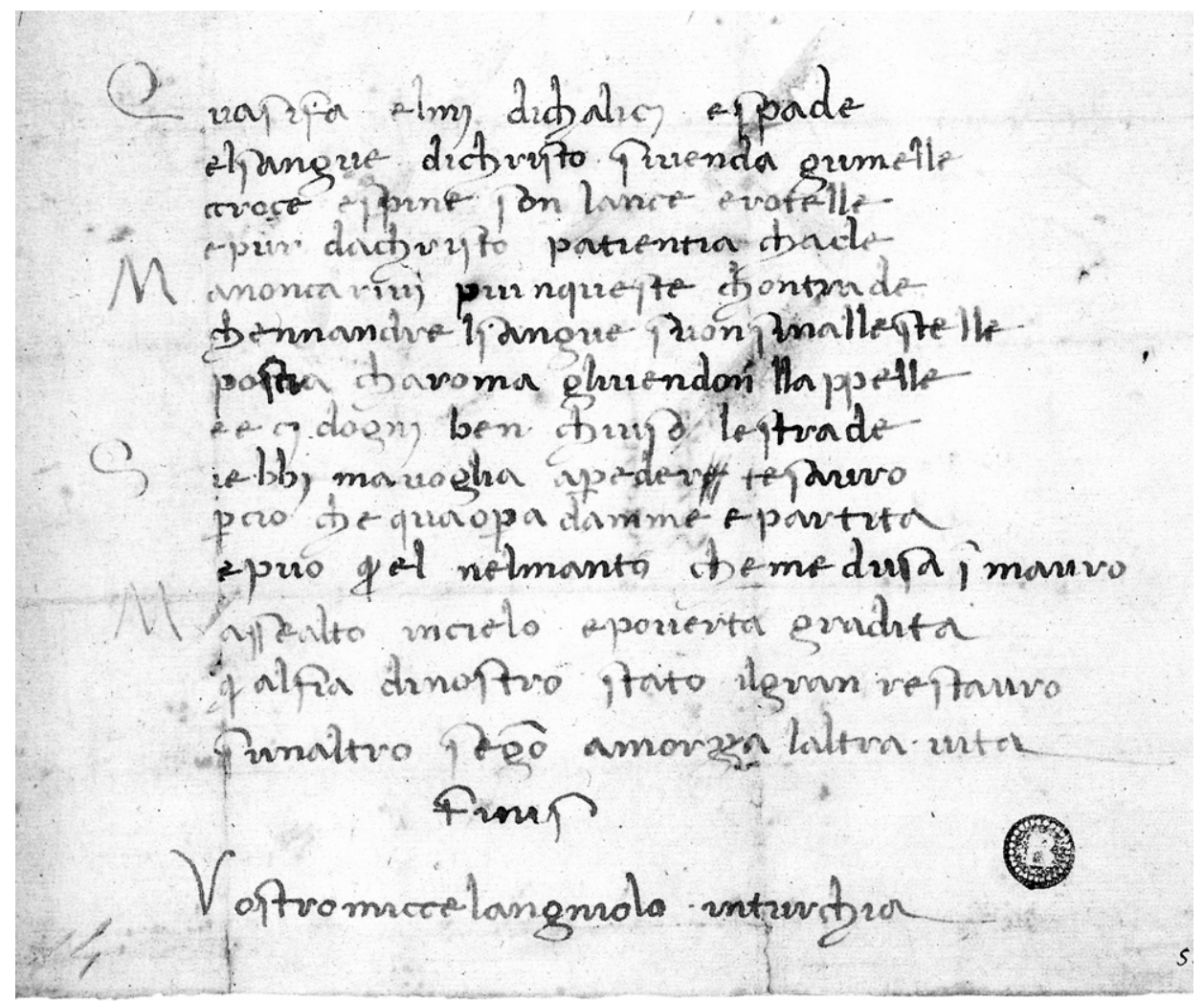

Figure 37. Michelangelo, autograph sonnet, 1497. Archivio Buonarroti, XIII, 110.

Qua si fa elmj di chalicj e spade

e 1 sangue di christo si uenda gumelle e croce e spine son lance e rotelle e pur da christo patientia chade.

Ma non ca riuj piu nqueste chontrade che nn andre 1 sangue suo nsin alle stelle poscia ch a roma gli uendon lla ppelle e ecj dognj ben chiuso le strade.

Si ebbj ma uoglia a $\mathrm{p}$ [er]eder tesauro $\mathrm{p}$ [er] cio che qua op[er]a da mme e partita e puo $\mathrm{q}[\mathrm{u}] \mathrm{el}$ nel manto che medusa $\mathrm{j}[\mathrm{n}]$ mauro

Ma sse alto in cielo e pouerta gradita $\mathrm{q}[\mathrm{u}] \mathrm{al}$ fia di nostro stato il gran restauro sunaltro seg[n]o amorzza laltra uita

finis

Vostro miccelangniolo in turchia 


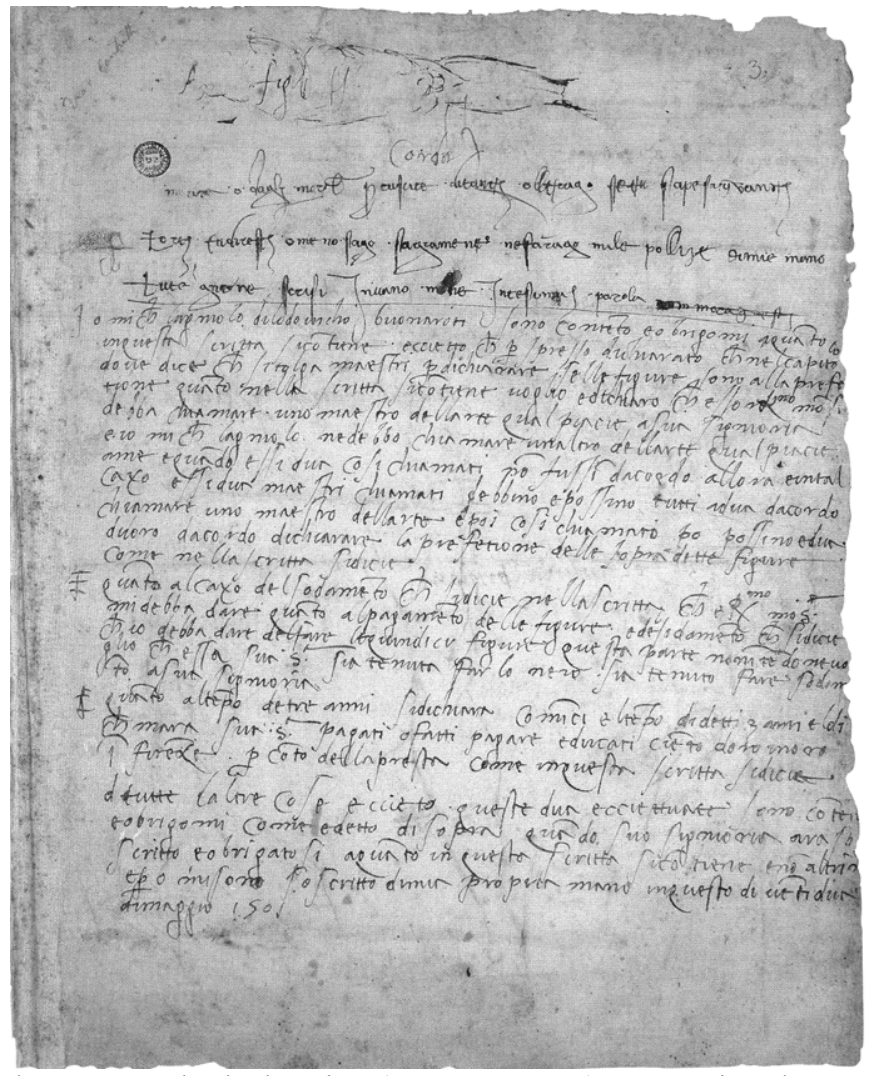

Figure 38. Michelangelo, autograph declaration (Dichiarazione) concerning the contract for statues for the Piccolomini Altar, 22 May 1501. Archivio Buonarroti, II-III, 3 verso.

Io michelagniolo di lodovicho buonaroti sono conte[n]to e obrigomi a qua[n]to in questa si co[n]tiene eccietto ch[e] p[er] spresso dichiarato ch[e] nel capitolo doue dice ch[e] si tolga maestri $\mathrm{p}$ [er] dichiarare se lle figure sono alla prefetione qua[n]to nella scritta si co[n]tiene uoglio e dichiaro ch[e] esso $\mathrm{R}^{\mathrm{mo}} \mathrm{mo}[\mathrm{n}] \mathrm{s}[$ igniore $]$ debba chiamare uno maestro dell arte qual piacie a sua signoria e io mich[e]lagniolo ne debbo chiamare un altro dell arte qual piacie a me e qua[n]do essi dua cosi chiamati no[n] fussi[n] dacordo allora e in tal caxo essi dua maestri chiamati debbino e possino tutti a dua dacordo chiamare uno maestro dell arte e poi cosi chiamato po[i] possino e dua di loro dacordo dichiarare la prefetione delle sopradette figure come nella scritta si dicie E qua[n] to al caxo del sodame[n]to ch[e] si dicie nella scritta ch[e] e R [evrerendissi ${ }^{\mathrm{mo}}$ $\mathrm{mo}[\mathrm{n}] \mathrm{s}$ [igniore] mi debba dare qua[n]to al pagame[n]to delle figure e de sodame[n]to $\operatorname{ch}[\mathrm{e}]$ si dicie $\operatorname{ch}[\mathrm{e}]$ io debba dare del fare le quindici figure questa parte non i[n]te[n]do ne uoglio ch[e] essa sua s[ignoria] sia tenuta far lo nero sia tenuto fare sodam[en]to a sua signoria E qua[n]to al tempo de tre anni si dichiara comi[n]ci el te[m]po di detti 3 anni el di ch[e] mara sua s[ignori] ${ }^{\text {a }}$ pagati o fatti pagare e ducati cie[n]to doro in oro in Fire[n]ze p[er] $\mathrm{co}[\mathrm{n}]$ to della presta come in questa scritta si dicie di tutte laltre cose eccieto queste dua ecciettuate sono co[n]ten[to] e obrigomi come e detto di sopra qua[n]do sua signoria ara soscritto e obrigatosi a qua[n]to in questa scritta si co[n]tiene e no[n] altri[menti] e p[er]o mi sono soscritto di mia propria mano in questo di ue[n]tidue di maggio 1501 


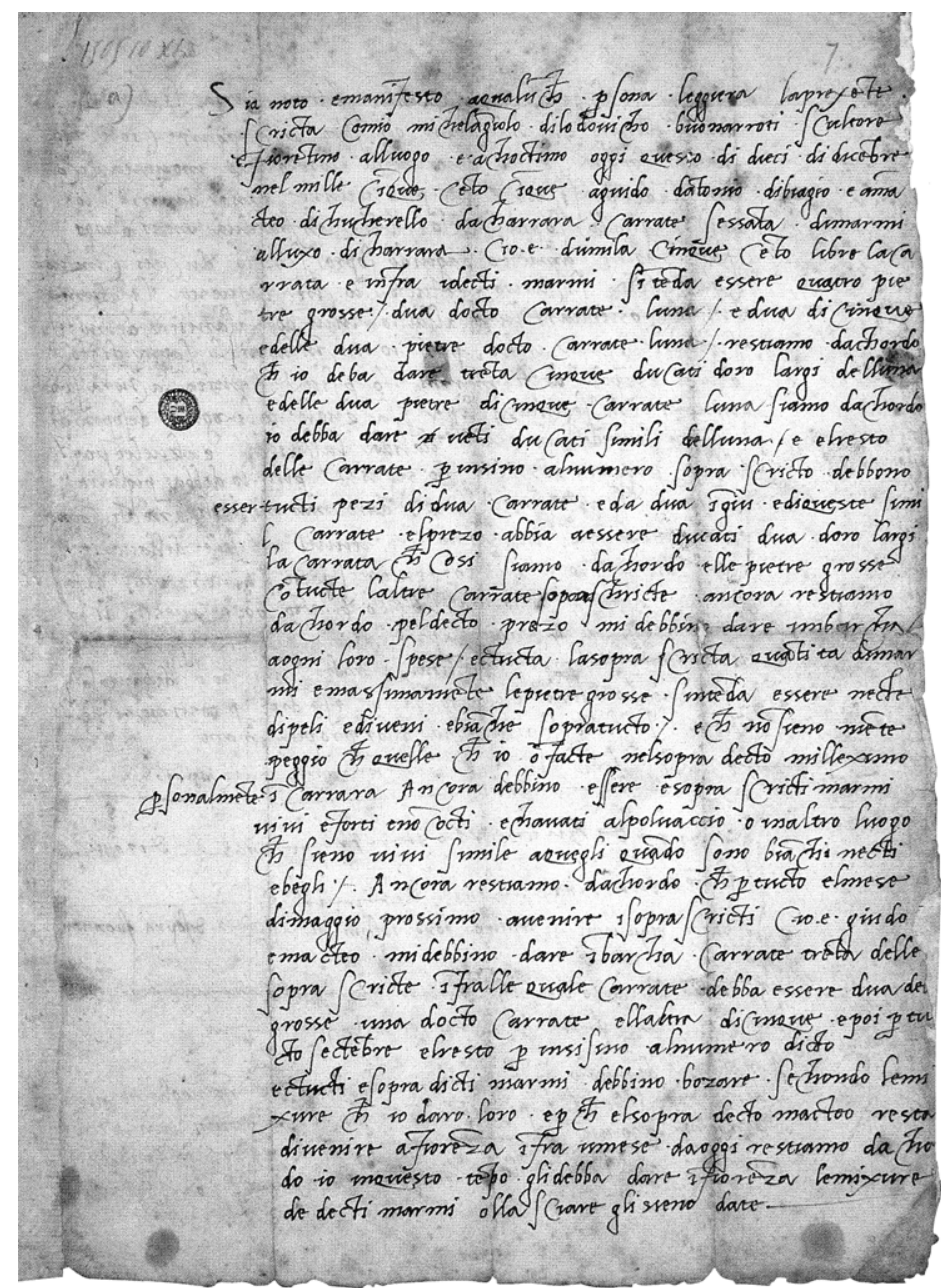

Figure 39. Michelangelo, autograph contract with quarry masters of Carrara for marble for the tomb of Julius II, 10 December 1505. Archivio Buonarroti, II-III, 7 recto.

Lines 1-21:

Sia noto e manifesto a qualu[n]ch[e] p[e]rsona leggiera la prexe[n]te scritta com io Michelag[n]iolo di lodovicho buonarroti scultore fiorentino alluogo e achottimo oggi questo di dieci di dice[m]bre nel mille ci[n]que ce[n]to ci[n]que a guido da[n]tonio di biagio e a [m] matteo di chucherello da charrara carrate sessata di marmi alluxo di charrara. Cioe dumila cinque ce[n]to libre la carrata e infra idetti marmi si[n]te[n]da essere quatro pietre grosse / dua dotto carrate luna / e dua di cinque e della dua pietre dotto carrate luna / restiamo dachordo $\operatorname{ch}[\mathrm{e}]$ io deba dare tre[n]ta cinque ducati doro largi delluna e delle dua pietre di cinque carrate luna siamo dachordo io debba dare ue[n]ti ducati simili delluna / e elresto delle carrate $\mathrm{p}$ [er] insino alnumero sopra scritto debbono esser tutti pezi di dua carrate e da dua i[n] giu e diqueste simil carrate elprezo abbia a essere ducati dua doro largi la carrata ch[e] choi siamo dachordo elle pietre grosse $\operatorname{co}[\mathrm{n}]$ tutte laltre carrate sopraschritte ancora restiamo dachordo pel detto prezo mi debbin dare im barcha a ogni loro spese / ettutta la sopra scritta qua[n]tita di marmi e massimame[n]te le pietre grosse si[n]tenda essere nette dipeli e diuevi e bia[n]che sopratutto / 


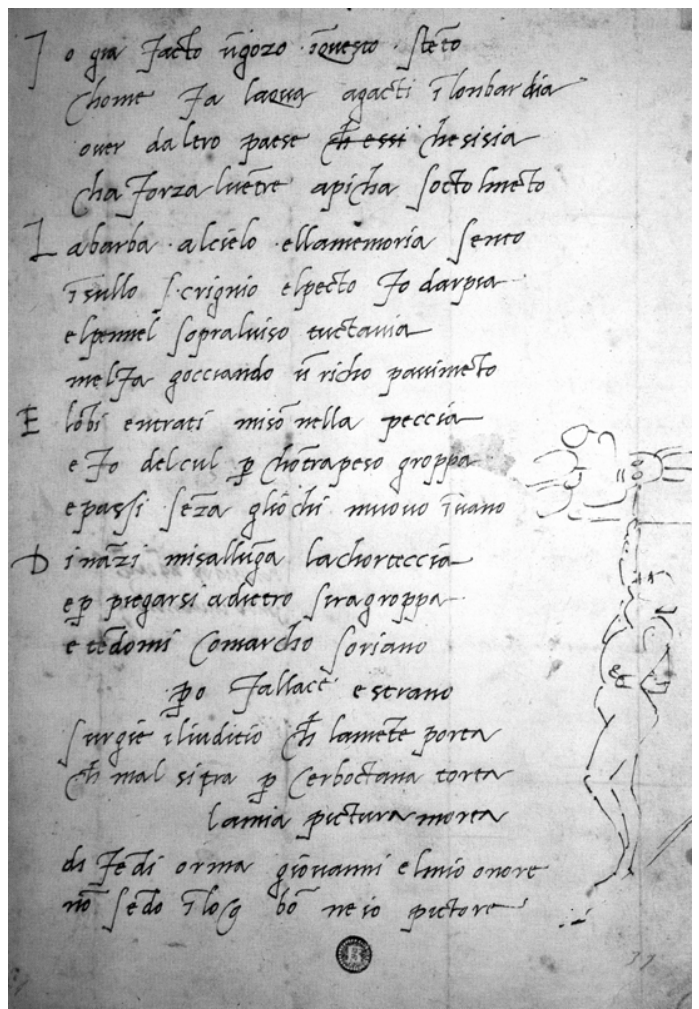

Figure 40. Michelangelo, autograph sonnet, 1508-12. Archivio Buonarroti, XIII, 111.

Io gia fatto [u]n gozo i[n] questo ste[n]to chome fa laqua agatti i[n] lombardia ouer daltro paese eh[e] essi che si sia cha forza $1 \mathrm{ue}[\mathrm{n}]$ tre apicha sotto $\operatorname{lme}[\mathrm{n}]$ to

La barba al cielo ella memoria sento $\mathrm{i}[\mathrm{n}]$ sullo scrigno e 1 petto fo darpia e 1 pennel sopra luiso tuttauia mel fa gocciando $u[n]$ richo pauime[n]to

$\mathrm{E}$ lo[m]bi entrati mi so[n] nella peccia e fo del cul p[er] cho[n]trapeso groppa e passi se[n]za gli ochi muouo i[n]uano

Dina[n]zi mi sallu[n]ga la chorteccia e p[er] piegarsi adietro si ragroppa e te[n]domi comarcho soriano pero fallace e strano surgie il iuditio ch[e] la me[n]te porta $\mathrm{ch}[\mathrm{e}]$ mal si tra $\mathrm{p}$ [er] cerbottana torta lamia pittura morta dife[n]di orma giovanni e lmio onore no[n] se[n]do i[n] loco bo[n] ne io pittore 


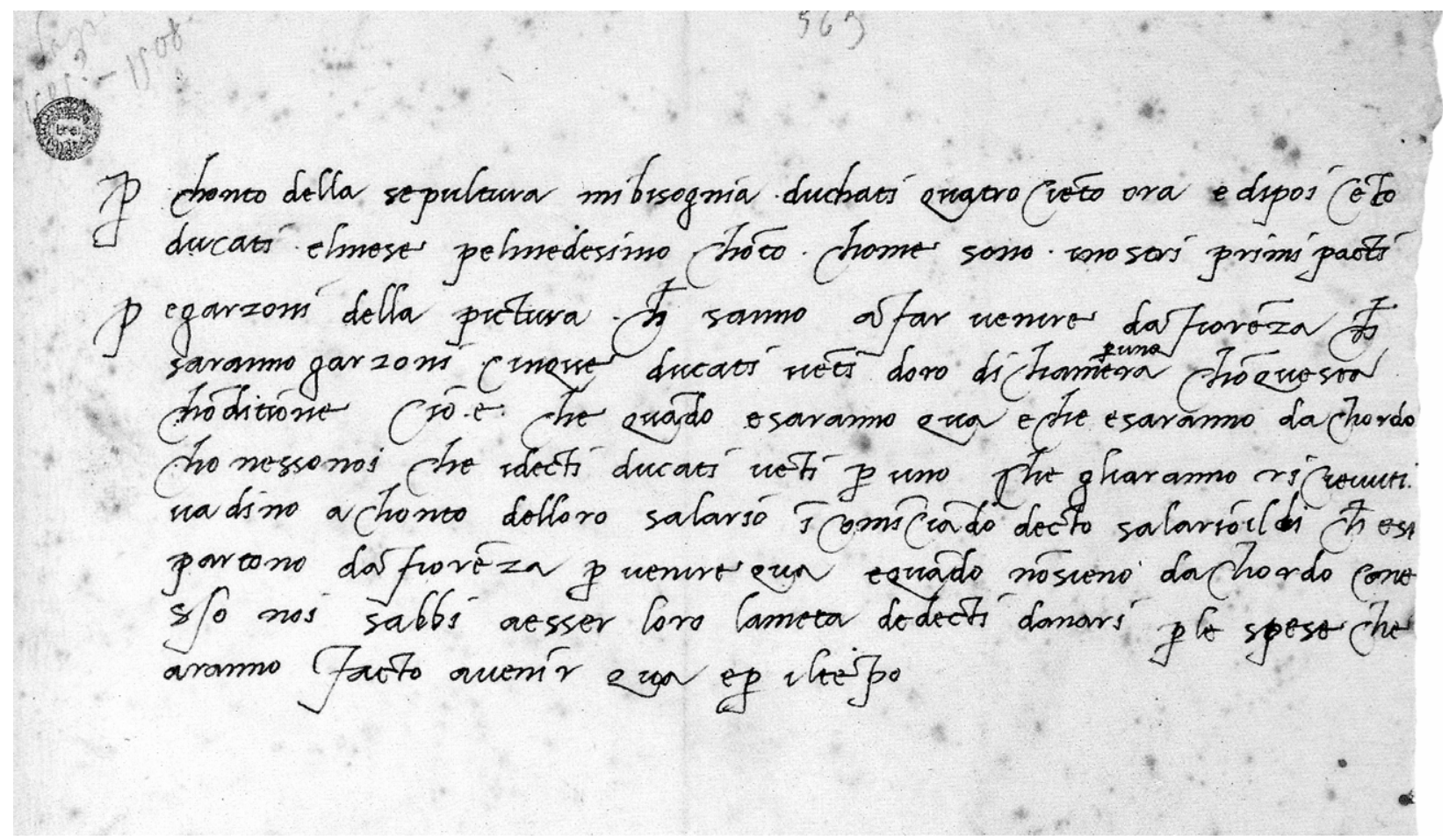

Figure 41. Michelangelo, autograph ricordo, April 1508 (detail). Archivio Buonarroti, I, 1.

$\mathrm{P}[\mathrm{er}]$ chonto della sepultura mi bisognia duchati quatro cie[n]to ora e dipoi ce[n]to ducati elmese pelmedesimo cho[n]to chome sono i nostri primi patti

Pegarzoni della pittura ch[e] sanno a far uenire da Fiore[n]za ch[e] saranno garzoni cinque ducati ue[n]ti doro di chamera ${ }^{\mathrm{p}[\mathrm{er}] \mathrm{eno}}$ cho[n] questa cho[n]ditione cioe che qua[n]do e saranno qua e che e saranno da chordo chon esso noi che i detti ducati ue[n]ti $\mathrm{p}[\mathrm{er}]$ uno che gli aranno ricieuuti uadino a chonto del loro salario i[n]comi[n]cia[n]do detto salario il di ch[e] si partono da Fiore[n]za p[er] uenire qua e qua[n]do no[n] sieno dachordo conesso noi sabbi aesser loro lameta de detti danari p[er] le spese che aranno fatto auenir qua e $\mathrm{p}$ [er] il te[m]po 


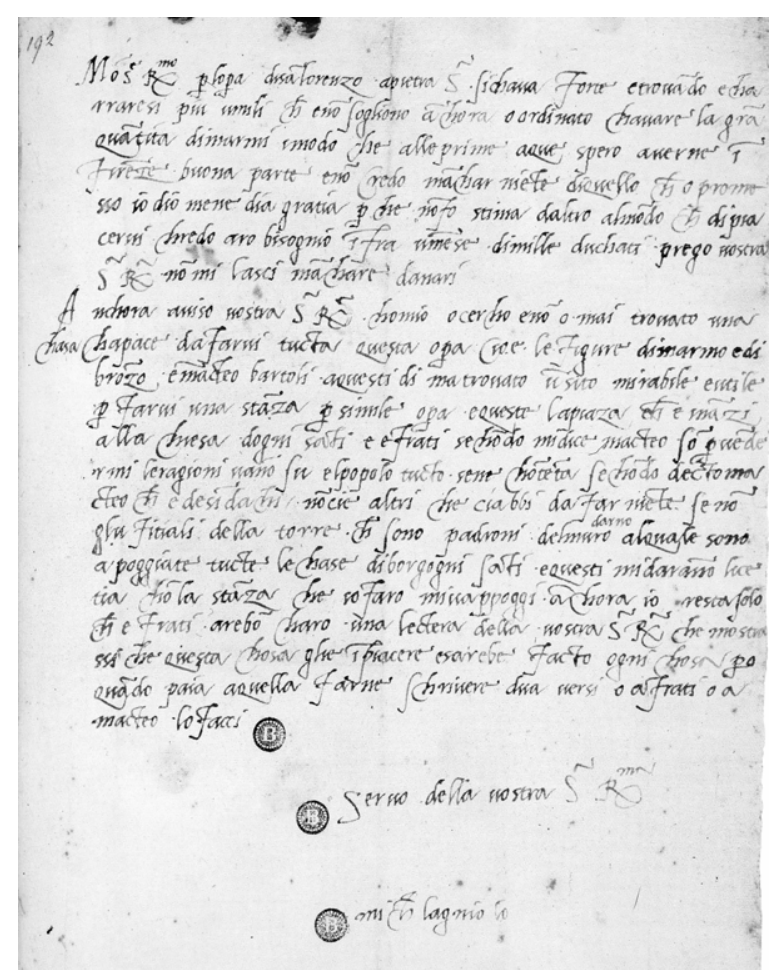

Figure 42. Michelangelo, autograph letter to Cardinal Giulio de' Medici, 1518. Archivio Buonarroti, V, 17.

$\mathrm{Mo}[\mathrm{n}] \mathrm{s}[\text { ignior }]^{\mathrm{e}} \mathrm{R}$ [everendissi $^{\mathrm{mo}} \mathrm{p}$ [er] lop[er]a di sa[n] Lorenzo a pietra S[anta] si chaua forte e troua[n]do e charraresi piu umili ch[e] e no[n] sogliono a[n]chora o ordinate chauare la gra[n] qua[n]tita di marmi i modo che alle prime aque spero auerne i[n] Fire[n]ze buona parte e no[n] credo ma[n]char nie[n]te di quello ch[e] o promesso io dio me ne dia gratia $\mathrm{p}[\mathrm{er}] \mathrm{che}$ no[n] fo stima daltro al mo[n]do ch[e] di piacerui chredo aro

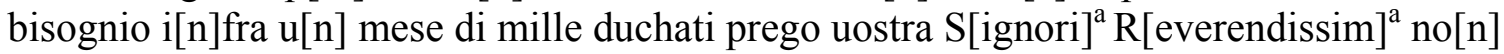
mi lasci ma[n]chare danari

Anchora auiso uostra $S[\text { ignori }]^{\mathrm{a}} \mathrm{R}\left[\right.$ [everendissim $^{\mathrm{a}}$ chomio o cercho e no[n] o mai trouato una chasa chapace da farui tutta questa op[er]a cioe le figure di marmot e di bro[n]zo $\mathrm{e}[\mathrm{m}]$ matteo bartoli a questi di ma trouato $\mathrm{u}[\mathrm{n}]$ sito mirabile e utile $\mathrm{p}$ [er] farui una sta[n]za $\mathrm{p}$ [er] simile op[er]a e quest e la piazza ch[e] e ina[n]zi alla chiesa dogni sa[n]ti e e frati secho[n]do mi dice matteo so[n] p[er] ve[n]dermi le ragioni $u$ an[n]o su e 1 popolo tutto se ne cho[n]te[n]ta secho[n]do detto matteo ch[e] e de si[n]dachi / no[n] ci e altri che ciabbi da far nie[n]te. se no[n] glufitiali della torre. $\operatorname{ch}[\mathrm{e}]$ sono padroni del muro darno alquale sono appogiate tutte le chase di borgogni sa[n]ti e questi mi daran[n]o lice[n]tia cho[n] la sta[n]z ache io faro mi uappoggi a[n]chora io resta solo ch[e] e frati arebo[n] charo una lettera della uostra $S\left[\right.$ ignori ${ }^{\mathrm{a}} \mathrm{R}$ [everendissim] ${ }^{\mathrm{a}}$ che mostrassi che questa chosa gli e i[n] piacere esarebe fatto ogni cosa $\mathrm{p}[\mathrm{er}] \mathrm{o}$ qua[n]do paia a quella farne schriuere dua uersi o a frati o a matteo lo facci

Seruo della uostra S[ignori $]^{\mathrm{a}} \mathrm{R}\left[\right.$ everendissi ${ }^{\mathrm{ma}}$ mich[e]lagniolo 

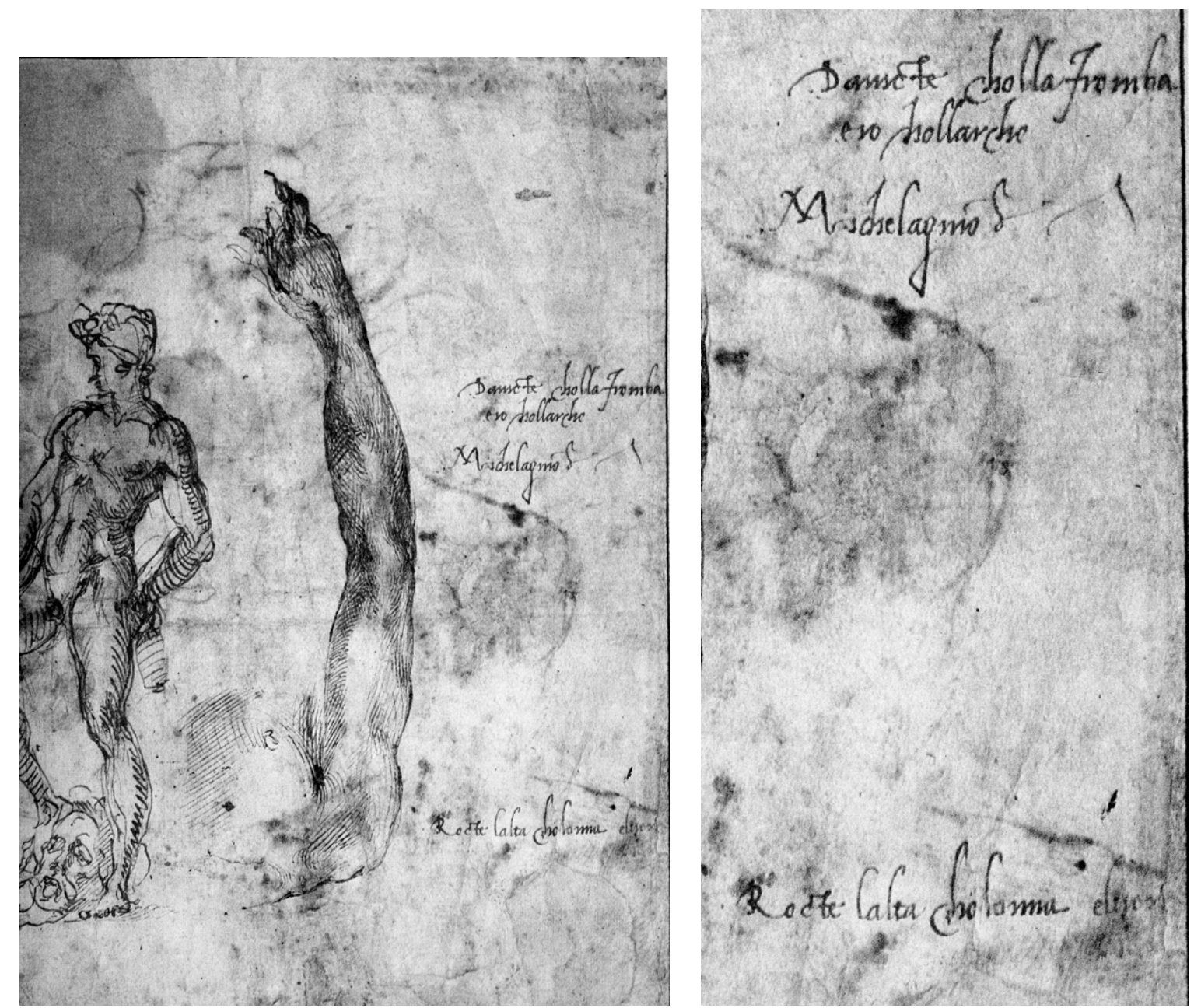

Figure 43. Michelangelo, Sketch for the Bronze David (and detail), 1501-2. Paris, Louvre, Cabinet des Dessins, INV\# 714 recto, and detail.

\section{Davitte cholla fromba} e io chollarcho

\section{Michelagniolo}

Rotte lalta cholonna el verd... 


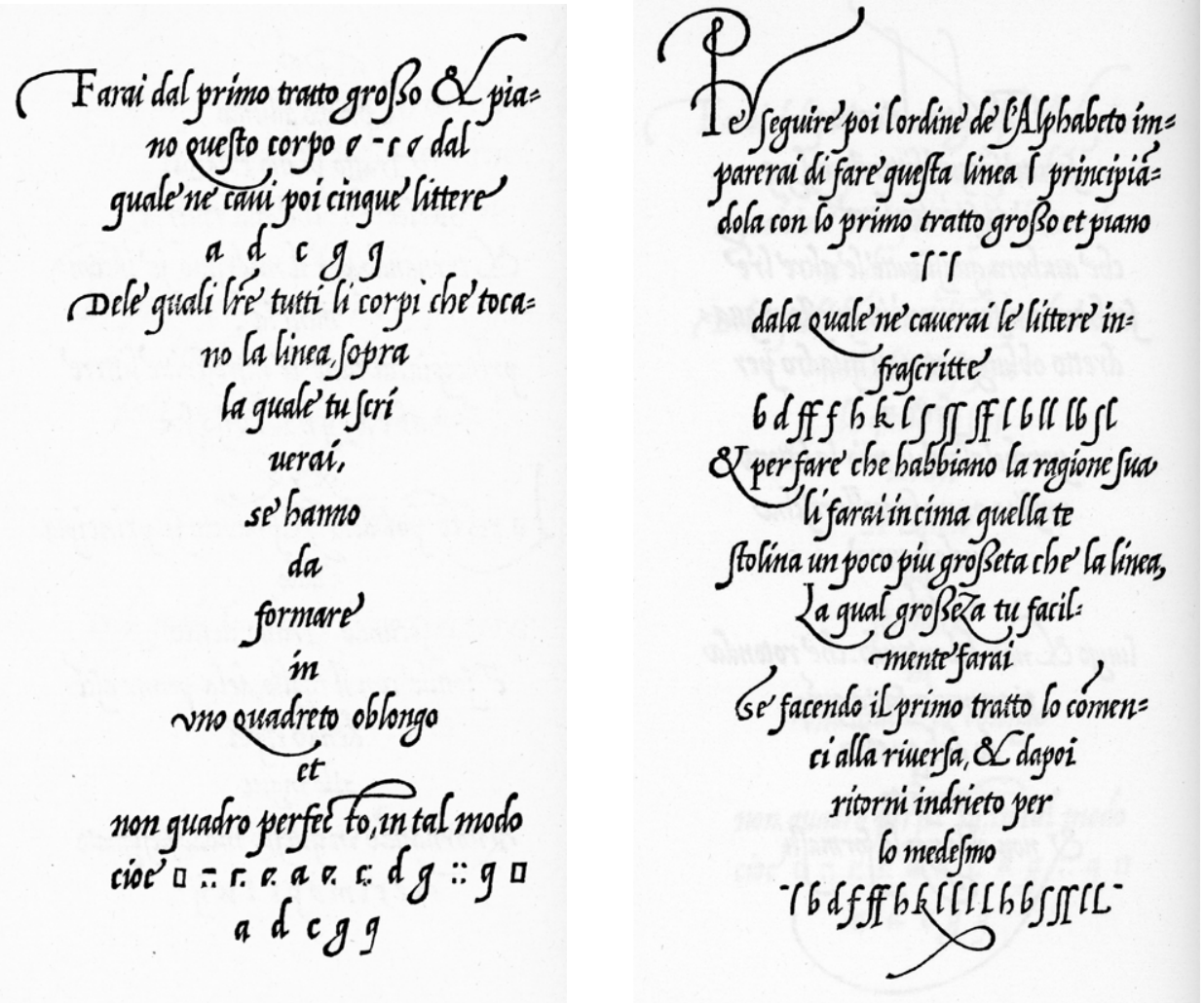

Figure 44. Arrighi, from La operina, 6 and 8.

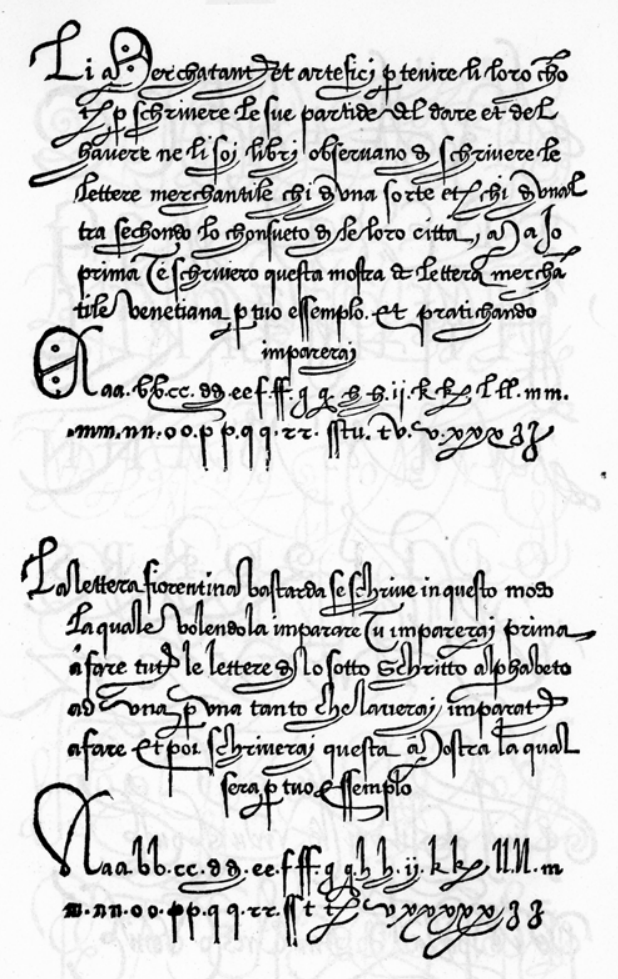

Figure 45. Tagliente, from Lo presento libro, 1524.

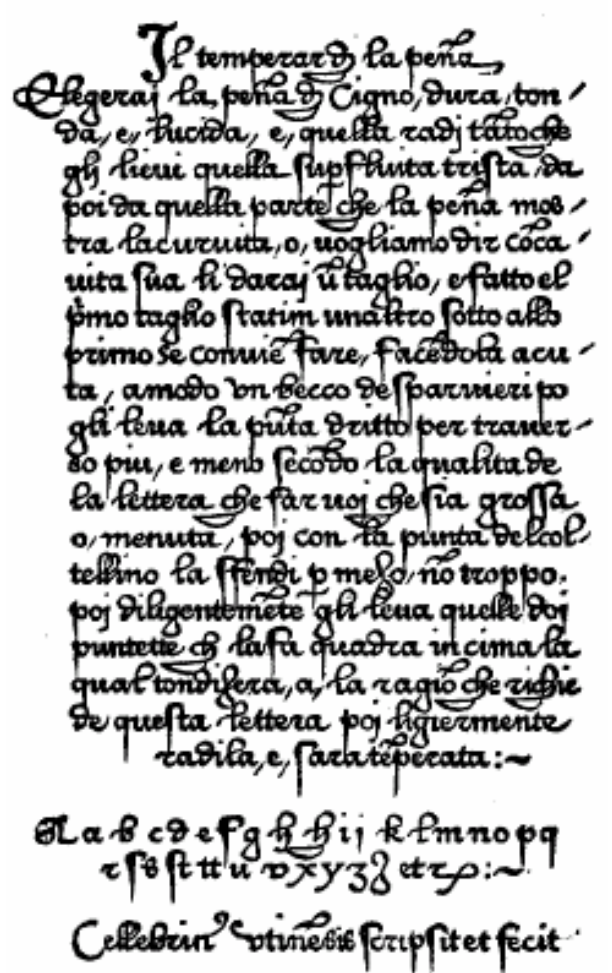

Figure 46. Celebrino, from Il modo, 1525. 


\section{Bibliography}

Arrighi, Ludovico Vicentino degli. La operina di Ludovico Vicentino, da imparare di scriuere littera Cancellarescha. Rome, 1522. Facsimile with trans. J. H. Benson, The First Writing Book: an English translation and facsimile text of Arrighi's Operina. New Haven: Yale University Press, 1954.

. Il modo de temparare le Penne con le uarie sorti de littere. Rome, 1523.

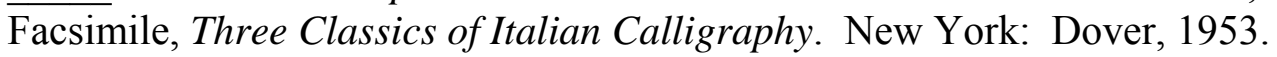

Bardeschi Ciulich, Lucilla. Costanza ed evoluzione nella scrittura di Michelangelo.

Florence: Cantini Editore, 1989.

Bischoff, Bernard. Latin Palaeography: Antiquity and the Middle Ages. Trans. Dáibhí ó Cróinin and David Ganz. Cambridge and New York: Cambridge University Press, 1990.

Black, Robert. "Italian Renaissance Education: Changing Perspectives and Continuing Controversies." Journal of the History of Ideas 52 (1991), 315-334.

Blunt, Anthony. Artistic Theory in Italy, 1450-1600. Oxford: Clarendon Press, 1962.

Brown, Julian. A Palaeographer's View: the selected writings of Julian Brown. Ed. Janet Bately, Michelle Brown, and Jane Roberts. London: Harvey Miller, 1993.

Brown, Michelle. A Guide to Western Historical Scripts from Antiquity to 1600. Toronto and Buffalo: Toronto University Press, 1993. . and Patricia Lovett. The Historical Source Book for Scribes. Toronto and Buffalo, NY: Toronto University Press, 1999.

Buonarroti, Michelangelo. Drawings of Michelangelo, 103 Drawings in Facsimile. Fwd. Mario Salmi, Introd. Charles de Tolnay, Critical Notes Paola Barocchi. Trans. A. T. Callen. New York: George Braziller, 1965.

Burckhardt, Jacob. The Civilization of the Renaissance in Italy. Trans. S. G. C. Middlemore. London and New York: Penguin Books, 1990.

Cast, David. "Humanism and Art.” In Renaissance Humanism (1988), vol 3., 412-449.

Celebrino, Eustachio. Il modo di Imparare di Scrivere lettera Merchantescha. Udene, 1525. Facsimile, Stanley Morison, Evstachio Celebrino da Vdene, Calligrapher, Engraver \& Writer for the Venetian Printing Press; With Illustrations in the text and a complete collotype facsimile of The Way of Learning to Write the Lettera Merchantescha by Evstachio Celebrino 1525. Paris: Pegasus Press, 1929. 
Condivi, Ascanio. The Life of Michelangelo. $2^{\text {nd }}$ ed. Trans. Alice S. Wohl, ed. Hellmut Wohl. Baton Rouge, LA: Louisiana State University Press, 1999.

The Correspondence of Erasmus. 12 vols. Toronto and Buffalo: University of Toronto Press, 1974.

de la Mare, Albinia C. The Handwriting of Italian Humanists, Vol. 1. Oxford and New York: Oxford University Press, 1973.

Derolez, Albert. The Palaeography of Gothic Manuscript Books: from the twelfth to the early sixteenth century. Cambridge and New York: Cambridge University Press, 2003.

Erasmus, Desiderius. Opus epistolarum Des. Erasmi Roterodami, denuo recognitum et auctum. 12 vols. Ed. P. S. Allen. Oxford: Clarendon Press, 1910.

Frommel, Christoph L. "Papal Policy: The Planning of Rome during the Renaissance." Journal of Interdisciplinary History 17 (1986), 39-65.

Goldscheider, Ludwig. Michelangelo Drawings. Text transl. R. H. Boothroyd. London: Phaidon Press, 1951.

Grafton, Anthony. Joseph Scaliger: A Study in the History of Classical Scholarship. New York and Oxford: Oxford University Press, 1993.

. "Quattrocento Humanism and Classical Scholarship." In Renaissance Humanism (1988), vol 3., 23-66.

Grendler, Paul F. “Schooling in Western Europe.” Renaissance Quarterly 43 (1990): 775-787.

Hartt, Frederick, and David G. Wilkins. History of Italian Renaissance Art. New York: H. N. Abrams, 1994.

Hughes, Anthony. Michelangelo. London: Phaidon Press, 1997.

. "A Lost Poem by Michelangelo?" Journal of the Warburg and Courtauld Institutes 44 (1981), 202-206.

Jackson, Donald. The Story of Writing. New York: Taplinger Publishing Co., 1981.

Kallendorf, Craig W., Ed. and transl. Humanist Educational Treatises. Cambridge, MA: Harvard University Press, 2002.

Kristeller, Paul O. Eight Philosophers of the Italian Renaissance. Stanford, CA:

Stanford University Press, 1964. 
. "Humanism." In The Cambridge History of Renaissance Philosophy, ed. Charles

B. Schmitt, Quentin Skinner, and Eckhard Kessler. Cambridge and New York:

Cambridge University Press, 1988.

Meiss, Millard. "Toward a More Comprehensive Renaissance Palaeography." Art Bulletin 42 (1960), 97-112.

Michelangelo: Grafia e Biografia, Disegni e autografi del Maestro. Ed. L. Bardeschi Ciulich and P. Ragionieri. Florence, Mandragora, 2004.

Milanesi, Gaetano. Le lettere di Michelangelo Buonarroti, edite ed inedite, coi ricordi ed i contratti artistici. Florence, 1875.

Morison, Stanley, and Nicolas Barker. Early Italian Writing-Books: Renaissance to Baroque. Boston: David R. Godine, 1990.

Palatino, Giovambattista. Libro nvovo d'imparare a scrivere tute sorte lettere antiche et moderne di tutte nationi, con nvove regole mesure et essempi. Rome, 1540. Facsimile, Three Classics of Italian Calligraphy. New York: Dover, 1953.

Poliziano, Angelo. Omnia opera Angeli Politiani. Aldus Manutius Romanus Marino Sannuto Leonardi filio patritio Veneto S. P. D. Venice, 1498.

Ramsden, E. H. The Letters of Michelangelo. 2 vols. Stanford University Press, 1963.

Renaissance Humanism : Foundations, Forms, and Legacy. Ed. Albert Rabil, Jr. 3 vols. Philadelphia : University of Pennsylvania Press, 1988.

Summers, David. Michelangelo and the Language of Art. Princeton, NJ: Princeton University Press, 1981.

Supino, Paola. "La scrittura di Angelo Poliziano." In Angelo Poliziano, Poeta, Scrittore, e Filologo. Ed. Vincenzo Fera and Mario Martelli. Florence : Le Lettere, 1998, 223244.

Tagliente, Giovantonino. Lo presento libro Insegna La Vera arte delo Excelle(n)te scriuere de diverse sorti de litere. Venice, 1524. Facsimile, Three Classics of Italian Calligraphy. New York: Dover, 1953.

Tolnay, Charles de. The Youth of Michelangelo. Princeton, NJ: Princeton University Press, 1943.

Ullman, Berthold L. The Origin and Development of Humanistic Script. Rome: Edizioni di Storia e Letteratura, 1960. 
Vasari, Giorgio. The Lives of the Artists. Trans. Julia. C. Bondanella and Peter Bondanella. Oxford and New York: Oxford University Press, 1991.

_. Le vite de' più eccelente pittori, scultori, e architettori. Di nuovo dal medisimo riviste et ampliate con i ritratti loro et con l'aggiunta delle vite de' vivi, \& de' morti dall'anno 1550 infino al 1567. Florence: Appresso i Giunti, 1568.

Vita di Michelangelo. Ed. L. Bardeschi Ciulich and P. Ragionieri. Florence, Mandragora, 2001.

Wardrop, James. "Civis Romanus Sum: Giovanbattista Palatino and his Circle." Signature 14 (1952), 3-39.

The Script of Humanism: Some Aspects of Humanistic Script 1450-1560.

Oxford: Clarendon Press, 1963. 


\title{
Robert J. Tallaksen
}

\author{
Curriculum Vitae
}

\section{Education:}

B.A., North Carolina State University, English, 1969

M.D., University of North Carolina, 1976

Internship, U.S. Naval Hospital, Bethesda, MD, July 1976-June 1977

Residency in Diagnostic Radiology, U.S. Naval Hospital, Bethesda, MD, July 1977 June 1980

Fellowship in Chest Radiology, Armed Forces Institute of Pathology, Washington, DC, July 1980-June 1981

\section{Current Position:}

Associate Professor of Radiology, School of Medicine, West Virginia University

\section{Professional Experience:}

Clinical Instructor, Department of Radiology, Uniformed Services University of the Health Sciences, Bethesda, MD, 1980-81

Clinical Assistant Professor, Department of Radiology, Uniformed Services

University of the Health Sciences, Bethesda, MD, 1981-84

Private practice of Radiology, 1984-2001; Radiological Consultants Association, later Radiological Physician Associates, Fairmont, WV.

\section{Publications:}

O’Tuama, L. A., R. J. Tallaksen, M. P. Remler, H. P. Nichols. "Accumulation of alpha[14C] aminoisobutyric acid by canine cranial meninges from cerebrospinal fluid in vitro." Journal of Neurochemistry 24 (1975), 581-3.

Karablut, N., D. R. Martin, M. Yang, R. J. Tallaksen. "MR imaging of the chest using a contrast-enhanced breath-hold modified three-dimensional gradient-echo technique: comparison with two-dimensional gradient-echo technique and multidetector CT." American Journal of Roentgenology 179 (2002), 1225-33.

\section{Papers Presented:}

"A Mystery Solved: Identification of an Unknown Manuscript in the West Virginia University Library," Southeast College Art Conference, Raleigh, NC, October 2003.

"The Handwriting of Michelangelo: Its Transformation from Gothic to Humanistic," SouthCentral Renaissance Conference, Malibu, CA, March 2005. 